\title{
Just What Word Did Mandel'shtam Forget? A Mnemopoetic Solution to the Problem of Saussure's Anagrams
}

\author{
Mikhail Gronas \\ Russian, Dartmouth College
}

\begin{abstract}
To the extent that memorability is one of the poet's chief (even if unconscious) concerns, poetic composition may be seen as a kind of mnemonic "reverse engineering" that utilizes the very operating procedures of verbal memory. In this article, I focus on the similarities between the cognitive operations involved in the tip-of-the-tongue phenomenon (a frustrating failure to retrieve a known but temporarily unavailable word) and those involved in creating the anagram, a poetic device discovered by Ferdinand de Saussure, in which the phonemes of the important theme word of a poem are dispersed throughout the body of the poem, while the word itself remains unsaid. Both the retrieval of a word on the tip of one's tongue and the (re)construction of an anagram involve sorting through the phonetic and semantic cues that hint at the absent target word. I suggest that these similarities may be due to the fact that both phenomena are subserved by a common cognitive mechanism: semantic and perceptual priming. On the basis of this analogy, I argue that in both ancient and modern literary traditions the anagram, whose origin puzzled Saussure, may have served a mnemonic function. The case study is provided by Osip Mandel'shtam's poem "I have forgotten the word that I wanted to

I am thankful to Penny Burt for invaluable help in preparing the manuscript and deRussianizing my English and to Meir Sternberg and Poetics Today reviewers for their insightful comments and demanding questions. At various stages of the development of this project, I greatly benefited from discussions with Valentina Apresian, Sergey Bratus, Grigory Dashevsky, Deborah Garretson, Carlo Ginzburg, Viacheslav Ivanov, John Kopper, Lev Loseff, Mikhail Makeev, Olga Meerson, Irina Paperno, Barry Scherr, Boris Uspensky, Maksim Yegorov, Viktor Zhivov, and Alexander Zholkovsky.
\end{abstract}

Poetics Today 30:2 (Summer 2009) Dol10.1215/03335372-2008-007

(C) 2009 by Porter Institute for Poetics and Semiotics 
say"- which both contains an anagram and presents an introspective analysis of the tip-of-the-tongue phenomenon.

If you want to understand a poem, the best thing is not to analyze it but to commit it to memory and recite it. Since the poet follows a phonetic trail, even what we might call a phonetic image, when you memorize his poem you repeat the whole process of his own creation from the beginning.

Joseph Brodsky, 1974

\section{On Mnemopoetics}

This article is a case study in a subfield of literary scholarship-one that I have provisionally termed "mnemopoetics." As the term itself implies, this is a field that borders on both poetics and cognitive science (or, more precisely, on the cognitive study of memory): it focuses on the mnemonic aspects of the creation, circulation, and reception of poetry.

Mnemopoetics begins with a commonsense observation: the one thing that sets poetry in traditional verse forms apart from any other kind is the fact that it is mnemonic. Indeed, all formal poetry might be described as a way to organize information mnemonically.

The importance of verbal memory in oral poetry-whose very survival obviously depends on the mechanisms of mnemonic transmission-has been recognized since the pioneering studies of Milman Parry (1953) and Albert B. Lord (196o). The underlying premise here is that preliterate societies need to select, store, and ensure the survival of the information they deem useful or valuable and, in the absence of more effective media, they resort to sheer brainpower and organize their myths and folklore mnemonically, by using recurrent schemes and patterns, formulas, meter, alliteration, rhyme, and so forth. Thus Mnemosyne, the goddess of memory, gives birth to the Muses. But the advent of writing eased the burden on our cultural memories - not necessarily to our own good, as Plato famously complained in the Phaedrus (274B-278B; 1995: 77-84). In classical antiquity and the Middle Ages, mnemonic practices retained their prominence mostly in the domain of rhetoric and oratory. And as written literature developed into the expected norm in modern Western cultures, we find these practices confined to the margins of discourse - to advertising jingles or to mnemonic aids like Roy G. Biv (the colors of the rainbow from red to violet). ${ }^{1}$

1. For a general theoretical account of the role that verbal memory plays in oral cultures and during the transition to literacy, see Walter Ong's seminal Orality and Literacy (1982: esp. $33^{-74}, 13^{8}-5^{6}$ ). For a more specific treatment of oral memory and the influence of writing in the West, particularly in ancient Greece, see a series of studies by Eric Havelock, beginning with his Preface to Plato (1963; see also Havelock 1971, 1976, 1982, 1986). For historical studies 
Mnemopoetics, however, contends that there is something to be gained from a mnemonic analysis of modern literary traditions as well. First, the appearance of new media - writing, print, or the Internet - does not solve the original problem of how and what to remember. A written literary culture is still confronted with a virtually boundless universe of cultural artifacts, all competing for the limited resources of society's attention and memory. Just because a work is written down, printed, or posted online offers no guarantee that it will even be noticed, much less remembered. In order to survive culturally, a text must still be memorable in some way or other, must be capable of sticking in the memory, and no less so than an ancient epos or a folk song: it must comply with the demands of individual readers' memories and fit in with the mechanisms of institutionalized cultural memory, otherwise known as the literary canon.

Second, even the archaic forms of literary memory that we associate with oral culture have survived into modernity in some genres, most importantly in poetry composed in traditional forms. Until quite recently, formal poetry in the West has led a "para-oral" existence, dependent on socially ingrained practices of poetry memorization: starting with the school, where the reciting of poetry learned by heart has served for centuries as a backbone of literary pedagogy, and continuing into adult life, where this poetry served as a mental stock of quotes, used both internally, to cope with and impart meaning to lived experiences, and socially, to mark one's cultural and educational status.

Modern practitioners of formal poetry have always been well aware of the mnemonic nature of their craft. One might cite, for example, the famous definition of poetry suggested by the young W. H. Auden: "Poetry is memorable speech" (Auden and Garrett 1935: 5). ${ }^{2}$

If memorability is indeed an important (even though not always conscious) concern of the poet, then our understanding of how poetry is created, perceived, and transmitted can be enriched by drawing upon the branch of knowledge that deals with memory proper, namely, cognitive psychology. Such an analysis has already been applied to oral poetry, most importantly by the cognitive psychologist David C. Rubin in his 1995

of mnemonic practices (ars memorativa) as part of rhetoric in classical antiquity, the Middle Ages, and the Renaissance, see Yates 1966; Hajdú 1967; Blum 1969; Small 1997; Carruthers and Ziolkowski 2002.

2. Seamus Heaney (2004), one of the last great defenders of poetic mnemonicity in the West, advocates the Joycean definition of poetry as "the rite words in the rote order" in a recent lecture. In the Russian tradition, Joseph Brodsky seems to have been a proponent of a mnemonic view of poetry. In interviews and oral presentations, while explaining the essence of poetry, he frequently referred to the mnemonic presence of memorized poems in readers' minds. Brodsky (1990) also famously made his American students learn poetry by heart, to their occasional discontent (Lamont 1974; Loseff 2007; Kopper 2007; Tischler 2005). 
book Memory in Oral Traditions: The Cognitive Psychology of Epic, Ballads, and Counting-Out Rhymes. Rubin has shown that in these oral genres, whose transmission and relative constancy depend on the ability of performers both to memorize and to improvise, such elements of poetic language as formulas, imagery, meter, alliteration, and rhyme provide mnemonic cues by limiting the number of possible verbal choices. ${ }^{3}$ Rubin's analysis focuses on transmission in oral genres and aims to elucidate the techniques that account for the relative constancy and mutations of oral texts as they pass through generations of performers. The goal of the present article is to show that a mnemonic view of poetry is relevant beyond oral literature. If mnemopoetics is to be applied to both the oral and the written traditions, including modern poetry, then its focus has to include not only the transmission but also the production of poetic texts. The mnemopoetic approach claims that, in a sense, every poem is mnemonic and an implicit concern for mnemonic efficiency informs, if not structures, the creative process.

I will try to demonstrate the cogency of the intimate relation between poetry and verbal memory by tackling a well-known mystery of historical poetics: the problem of the origins of the anagram, that mysterious poetic device that reproduces a sacred name or a theme word within the body of a poem. Ferdinand de Saussure was the first to see this device as an integral part of Indo-European poetics; and in the latter years of his life, he was increasingly preoccupied by this subject as he detected anagrams in an ever wider range of ancient and modern texts. However, he never published any results of this research. He never found either an explicit description or any independent proof of the conscious use of anagrams in any ancient treatise on poetics: that is, he was uncertain of the historical origins and basic functions of the device and thus was never sure whether the anagrams were a creation of his own fantasy or an actual device in the text.

This article aims at finding a possible solution to Saussure's problem by way of a mnemopoetic reading of a poem by Osip Mandel'shtam, with a little help from cognitive science.

\section{The Mystery of the Anagram}

In 1905, while working on the lectures that would become the basis for his famous Course in General Linguistics, Saussure became interested in what at

3. Interest in the mnemonic basis of epic poetry was initiated by the classic studies of Lord (1960) and Parry (1953). For an overview of the vast literature on the Oral Formulaic Theory that grew out of Lord and Parry's pioneering works, see Foley 1988. See Rubin 1995 for a detailed cognitive account of the mnemonic functioning of rhyme/meter and imagery in oral traditions. 
first seemed like a curious philological side project, focused on the mechanism of ancient Latin Saturnian verse. ${ }^{4}$ Saturnian verse is the oldest form of Latin versification, surviving in the form of fragments, mostly epitaphs and oracular utterances, quoted in later Latin texts. The nature of the verse was obscure in Saussure's time and has remained so up to the present day: some scholars think that the meter was syllabic, while others maintain that it was tonal (i.e., stress based). ${ }^{5}$ Saussure was not satisfied with either theory and felt that there must be some rule (beyond stress or syllable count) that governed this archaic meter.

His intuition was that a certain pattern could be detected in the distribution of consonants and vowels in Saturnian verse. First, he came up with what he called the law of pairing (couplaison): any consonant or vowel that appeared in a line had to be used twice, so that each sound had a pair within that same line. This law worked with some, but not all, of the surviving examples. While trying to modify this law to make it more flexible, he found, to his own amazement, an even stranger pattern. Some Saturnian lines seemed to include all the phonetic components (either syllables or phonemes) of a particular word-most often, a proper name never mentioned explicitly in the poem but one that was especially relevant to the content of the line or the poem as a whole, such as the name of the person to whom the poem was addressed or dedicated or of the god or mythological hero who was the subject of the poem.

For example, in an ancient vaticinium, a short poem addressed to the Romans by the god Apollo through the Delphic Oracle, Saussure found a line that includes, in two almost correct sequences, the sounds contained in the name of Apollo:

Donom amplom victor ad me $a$ templa portato

O A PLO O A A PLA PO O

(Bring in victory a splendid gift to my temple. $)^{6}$

The ancient poets seemed to be concealing an important thematic word of the poem (frequently the name of the god to whom the poem is addressed or ascribed) but dispersing phonetic clues to that word throughout the body of the poem. Thus the Latin vaticinium cited above is an oracular

4. For an account of Saussure's research on the anagram, see Starobinski 1979; Wunderli 1972.

5. For a review of approaches to Saturnian verse, see Cole 1969; Luiselli 1967. For an analysis of the possible Indo-European source of the meter, see West 1973. For a skeptical view of both the law of pairing and the anagram in Saturnian verse, see Rastier 1970.

6. Quoted in Starobinski 1979: 51. The vaticinium is reported in Livy's history of Rome (5.16). The quotation is Saussure's phonetic reconstruction of the original text from Livy's Augustan Latin. 
utterance ascribed to Apollo himself. Apollo addresses the Romans, foretells their success in the protracted war against the Etruscan city of Veii, and instructs them to thank him for this victory by renewing the sacrificial rituals at his temple at Delphi: "Victory has been vouchsafed you by the fates, which are herein revealed, over this city you have long besieged. At battle's end you must bring in victory a splendid gift to my temple and must repeat in ancestral fashion those sacred rites of your country that you have failed to carry through" (Livy 2005: 300).

The line that attracted Saussure's attention (emphasized in the translation above) refers to two symbolic attributes of Apollo, the gift, along with the rites owed to him and his temple, thus providing semantic pointers to Apollo. At the same time, the sounds of the name Apollo are dispersed along the text of the line, so that by forming together pieces of meaning and sound, one can reconstruct the name that is never mentioned as such. Trying to capture the essence of the phenomenon, Saussure coined several terms: logogram (the word out of [dispersed] letters), hypogram (the word "below letters"), paragram (the word "alongside letters"), and many others (Wunderli 1972: 42-54; Callus 2002a). He finally chose the term anagram (the word "written anew"), thus emphasizing the similarity-although risking a confusion - with the traditional anagram, that is, a wordplay based upon rearranging the letters of a word or phrase to produce a new word or phrase, such as "Homo Sapiens-ape's son, IMHO" (Noam Elkies, reported in Cipra 2003).

Saussure soon began to find anagrams in other poetic traditions as well. Writing on Vedic poetry, for example, he notes that "hymns dedicated to [the god] Agni Angiras are a series of puns, like girah (songs) and anga (conjunction), etc. - demonstrating the essential preoccupation with imitating the syllables of a sacred name" (quoted in Starobinski 1979: 23). He also found anagrams in Homer, in the classical Latin poets, and finally in medieval and even modern Latin poetry.

He himself realized that all this might be merely his own obsession, a sort of scholarly paranoia. One way to prove or disprove his hypothesis would have been to devise a statistical test to check if what he saw as a pattern, an anagram, was in fact a random phenomenon. This, however, was beyond the reach of the statistical linguistics of Saussure's time and, in all likelihood, remains so even now. ${ }^{7}$

7. In the unanswered letter to Giovanni Pascoli, Saussure discusses and then discards the possibility of a statistical verification: "The greater the number of examples becomes, the more reason there is to think that what must be producing these coincidences quite regularly is the natural play of chance working over the 24 letters of the alphabet. Since the calculation of the probabilities in these cases would require the skill of a seasoned mathematician, 
Another, seemingly more accessible way to base the hypothesis on firm empirical ground would be a historical or philological proof. If so many poets in so many cultures have used this device and, as Saussure believed, have done so consciously, there should be at least some evidence of this fact in treatises on poetry or poems about poetry. But Saussure never found a definitive answer to the question of how anagrams originated and what their function might have been, nor did he find any independent historical evidence of their existence.

Some excerpts from his notebooks are indicative. This first has to do with Saussure's approach to the question of origins:

What do we know of the reason which interwove anagram into the short lyric pieces we place at the foundation of poetry?

The reason might have originated in the religious idea that an invocation, prayer, or hymn would have power only if the syllables of the divine name were worked into the text....

The reason might have been nonreligious, purely poetic: ${ }^{8}$ of the same order as that which elsewhere governs rhyme, assonance, etc.

And so on. So that desire to say-for any period-why something exists reaches beyond the fact, and there is no greater reason for expressing it in regard to epic poetry than in regard to any other, if one admits a historic chain of which we do not with certainty understand even the first link. (Ibid.: 42)

Saussure thus offers a number of hypotheses, but he is not particularly preoccupied with the question of origins. Here we see him applying his own dichotomy of diachrony versus synchrony: from the synchronic point of view, the question of history is not particularly important. As Jean Starobinski (ibid.: 41) notes: "Saussure only rarely questioned himself on the origin of the process he attributed to Greek and Latin poets. It was enough for him to be able to confirm that this trait could be established in every period, like a permanent manufacturer's secret."

However, the fact that such a widespread phenomenon was nowhere documented, described, or even mentioned in any of the traditions in which it is found presented a more serious problem. Again, Saussure's notebooks tell of his futile search for evidence:

I find it quicker and more reliable to appeal to the very person [i.e., Pascoli, whom Saussure considered to be an anagrammatic poet] who can inform me about the significance that should be attached to these juxtapositions of sounds" (Nava 1968: 81). Some attempts at statistical analysis can indeed be found in Saussure's notebooks (Starobinski 1979: 97).

8. By "purely poetic" reasons, Saussure most likely means the phonetic expressiveness or sound ornamentation of a verse. Elsewhere (Starobinski 1979: 17; see also Lotringer 1973: 3) he comes close to equating the anagram to paronomasia, a traditional poetic device that plays on similar-sounding words. 
As such an allusion [to the anagram] has never been reported, one must assume that ancient theorists of Latin versification refrained as a matter of course from mentioning an elementary and primary condition of this versification. Why they should have kept silent on this point is a question to which I have no answer, and which, in view of the scrupulous observation by all poets . . . [interrupted text]. (Ibid.: 102)

Here the text ends abruptly, and Starobinski (ibid.: 103), the first publisher of Saussure's notebooks, notes that this was "a significant interruption, which marks a stumbling block. The rule, so rigorously observed and handed down throughout the generations, is not referred to in any way, throughout literature."

Then, on the same page, Saussure continues the interrupted train of thought:

I can see no other way but to present the puzzle as it appears to me.

I have no further explanation of the fact, so difficult to understand or believe, that not a single Latin author writing a De re metrica or discussing poetic composition in a general way should appear to know, or even to wish to know, that the fundamental basis of poetic composition is to take as a framework the logograms [i.e., anagrams: Saussure is using here one of his alternative terms] of a name or of a phrase. (Ibid.)

Starobinski (ibid.: 94) nicely summarizes Saussure's doubts and embarrassment:

One only finds what one seeks, and Saussure sought a phonetic constraint added to the traditional metrics of the poetic line. It remains to be seen if the rules he sought and found in his readings of the ancient poets correspond to a law these poets consciously followed. Nothing, then, appears more essential than finding among the ancients an external witness to confirm the existence of a law or tradition which was actually observed. Ferdinand de Saussure looked for this witness but found nothing definitive, only an embarrassing silence.

In his obsession, Saussure found anagrams everywhere, even in poems by his contemporaries. One of these was Giovanni Pascoli (1855-1912), the great Italian poet who wrote in both Italian and Latin. Inspired by all the anagrams he had found in Pascoli's Latin writings, Saussure wrote the poet a letter asking for explanations, hoping that this would finally lead him to a solution to the mystery. Pascoli (no doubt perplexed by this odd inquiry) never answered. ${ }^{9}$ For Saussure, this must have been the last straw,

9. Saussure first wrote to Pascoli a short introductory letter in which he asked the poet if he would be willing to help. Upon receiving a positive answer, Saussure sent a detailed inquiry with anagrammatic examples from both ancient poetry and Pascoli himself: this 
because he then abandoned his research and never published anything on the topic.

In the 196os and 1970s, following the publication of Saussure's notebooks, the anagram became a topic of heated polemics among philologists, literary scholars, psychoanalysts, and philosophers. Scholarly reactions to Saussure's anagrammatic studies can be roughly divided into three groups. Skeptics denied the anagram any reality whatsoever and considered it the great linguist's "folly" (Deguy 1969; Rastier 1970). Philosophers and literary critics grouped around the French journal Tel Quel, most notably Julia Kristeva, greeted the advent of the "second Saussure" and emphasized those aspects of the anagram that were in tune with the then nascent poststructuralist zeitgeist, such as the anagram's nonconformity with Saussure's own postulates of the arbitrariness and linearity of the sign or with the opposition of signified and signifier (Kristeva 1969; Lotringer 1973; Baudrillard 1993: 195-213). Finally, other scholars, led by Roman Jakobson, enthusiastically accepted Saussure's findings at their face value. Heaps of anagrams were discovered in poet after poet, both in modern poetic traditions and in antiquity. ${ }^{10}$ However, Saussure's questions - what was the original function of the anagram and why, if it was so prevalent, nobody seemed to mention it explicitly- have not yet been answered. In what follows, I will show that an application of the mnemopoetic approach may shed light on both of these questions. In broad outline, my argument is that in both ancient and modern poetry the anagram may have served a mne-

letter remained unanswered. Saussure's letters are reproduced in Nava 1968. On Saussure's anagrammatic readings of Pascoli, see Rosetti 1976; Rossi 1968.

10. For a bibliography of research related to Saussure's notebooks, see Callus 2002b. Following the publication of Saussure's notebooks, anagrams have been observed in the reconstructed Indo-European poetics (Ivanov and Toporov 1975), in Vedic texts (Shepheard 1983; Elizarenkova 1995; see Matasovic 1996 for a review), in Russian medieval epos and folklore (Jakobson 1966; Toporov 1999), in troubadour poetry (Meylakh 1978; Hardy and Brodovitch 2003), in Dante (Gorni 1990), in Petrarch and Pierre Ronsard (Starobinski 2005), in Guillaume de Machaut (De Looze 1988), in Maurice Scève (Risset 1995), in Shakespeare (Jakobson and Jones 1970; Gagliardo 1996; Ricks 2002; Winnick 2005), in Friedrich Hölderlin (Jakobson 1976), in Lord Byron (White and Beazel 1991), in E. A. Poe (Rodríguez Ferrándiz 1998), in James Joyce (Bevis 2007; Camilleri 1983), in Vladimir Nabokov (Shapiro 1991; Guy 1996; Katz 1999), in T. S. Eliot (Johnson 1976), in Charles-Pierre Baudelaire (Jakobson 1967), in Arthur Rimbaud (Bachellier 1973), in Stéphane Mallarmé (Ossola 1979; Temple 1995), in René Char (Mathieu 1984), in Jean Ricardou (Higgins 1982), in Blas de Otero and Antonio Machado (Herrero Blanco 1996; Rodríguez Ferrándiz 1998), in Aleksandr Blok (Levinton and Smirnov 1979), in Anna Akhmatova (Meylakh 1975; Loseff 1986), in Velimir Khlebnikov (Jakobson 1980), and in Mandel'shtam (Ivanov 1972; Ronen 1973: 368-70; Kahn 1994). This list is far from complete and is only meant to give an idea of the chronological and geographical range of the research on anagrams. For a comprehensive overview of anagrammatic research, see Rodríguez Ferrándiz 1998; Gandon 2002. 
monic function, being a by-product of mnemonic processes taking place in the poet's creative mind. But to get there I will first make a detour and turn to a seemingly unrelated subject, the poem "Swallow" ("Lastochka") written by Mandel'shtam in 1920.

\section{A Tip-of-the-Tongue Poem}

It is difficult to imagine a text better suited for a mnemopoetic analysis than Mandel'shtam's "Swallow." Here a mnemonic process is not merely moved to the foreground but is made into the very theme of the poem. ${ }^{11}$

Я слово позабыл, что я хотел сказать.

Слепая ласточка в чертог теней вернется, На крыльях срезанных, с прозрачными играть.

В беспамятстве ночная песнь поется.

Не слышно птиц. Бессмертник не цветет.

Прозрачны гривы табуна ночного.

В сухой реке пустой челнок плывет.

Среди кузнечиков беспамятствует слово.

И медленно растёт, как бы шатер иль храм,

То вдруг прикинется безумной Антигоной,

То мертвой ласточкой бросается к ногам,

$\mathrm{C}$ стигийской нежностью и веткою зеленой.

$\mathrm{O}$, если бы вернуть и зрячих пальцев стыд,

И выпуклую радость узнаванья.

Я так боюсь рыданья аонид,

Тумана, звона и зиянья!

А смертным власть дана любить и узнавать, Для них и звук в персты прольется, Но я забыл, что я хочу сказать, -

И мысль бесплотная в чертог теней вернется.

Всё не о том прозрачная твердит,

Всё-ласточка, подружка, Антигона . . .

И на губах, как черный лед, горит

Стигийского воспоминанье звона.

(variant of the last stanza):

А на губах как черный лёд горит

11. Throughout his life, Mandel'shtam was preoccupied with the theme of memory and its poetic significance. On the more general philosophical and biographical aspects of memory in Mandel'shtam and the mnemonic nature of his imagery, see Lekmanov 1998: 575-78; Benchich 1997; Pavlov 1998. 
И мучит память: не хватает слова.

Не выдумать его оно само гудит, Качает колокол беспамятства ночного.

(Mandel'shtam 1990, 1:130-31)

(I have forgotten the word that I wanted to say.

On clipped wings the blind swallow will return

To the palace of shades to play with the transparent ones.

A night song is sung in forgetfulness.

You couldn't hear a bird. The immortelle doesn't bloom.

The manes of night's herd of horses are transparent.

An empty canoe glides on a waterless river.

The word is forgotten amidst the grasshoppers.

And it swells slowly, like a tent or temple,

One moment suddenly pretends to be the crazed Antigone,

Lands at one's feet the next, like a dead swallow,

With Stygian tenderness and a green branch.

$\mathrm{O}$, if I could bring back the shame of seeing fingers

And the rounded joy of recognition.

I am so afraid of the Aonides' weeping,

Of mist, ringing, the abyss.

Yet the power to love and recognize is given to mortals,

For them even the sound pours through their fingers,

But I forgot what I wanted to say, -

And the unbodied thought will return to the palace of shades.

The transparent [thought] keeps on repeating the wrong thing,

Again and again: swallow, friend, Antigone ...

But on the lips, like black ice, burns

The remembrance of the Stygian ringing.

[Variant] But on the lips, like black ice, [it] burns,

And torments memory: the word is lacking.

You can't invent it; [the word] itself is droning

And rocking the bell of nightly forgetfulness. $)^{12}$

There have been many commentaries on this poem, but one particular fact seems to have escaped scholarly attention: namely, that the poem is itself a quite accurate and detailed description of the common cognitive phenomenon known as the "tip-of-the-tongue" state, that is, the frustrating failure to retrieve a word that the speaker knows but cannot quite remember. ${ }^{13}$

12. Unpublished translation by Jane Miller, modified by Penny and used here with their permission.

13. Scholars have documented a wealth of mythological allusions merged together in the 
The tip-of-the-tongue state is described quite literally in the very first line of the poem: "Ia slovo pozabyl, chto ia khotel skazat" (I have forgotten the word that I wanted to say). The blind swallow of the next line- "Slepaia lastochka v chertog tenei vernetsia" (the blind swallow will return / To the palace of shades) - is a metaphor for the thought that is never made word. The image is further clarified in the fifth stanza:

Но я забыл, что я хочу сказать, -
И мысль бесплотная в чертог теней вернется.

(But I forgot what I want to say,-

And the unbodied thought will return to the palace of shades.)

Thus the blind swallow is an unembodied thought, a thought that has yet to become a word. This swallow/thought flies back to the "palace of the shades," that is, to the preverbal cognitive layer of consciousness, to play with "the transparent ones" - other preverbal entities. Mandel'shtam may have chosen the image of the swallow because there is a common Russian

poem-references to the myths of Orpheus and Eurydice, Cupid and Psyche, Oedipus and Antigone, to the descriptions of the netherworld in the Odyssey and the Aeneid (see Taranovsky 1976; Osherov and Barsova 1995; Kovaleva 2005) - as well as allusions to the poems of Mandel'shtam's contemporaries Nikolai Gumilev, Mikhail Lozinskii, and Akhmatova (Ronen 1977). The commentators have agreed that the basic plot of the poem is, in the words of Omri Ronen (ibid.: 177), "a description of the act of recollection in terms of the Orphic or Eleusinian katabasis," a fusion of mythological and mental spaces (see also Freidin 1987: 204; Ginzburg 1974; Przybylski 1987: 54-55). The present interpretation is built upon these readings in that it also treats the poem as an attempt to verbalize and mythologize a psychological process. However, as distinct from previous interpreters, I emphasize what might be called Mandel'shtam's "cognitive naturalism," i.e., his realistic description of the specific and concrete details of an ordinary psychological phenomenon (the tip-of-the-tongue state). This emphasis on the ordinary is important as it also differentiates my reading of the focal image of the poem, the forgotten word, from the ones suggested by previous interpreters of the poem, who have tended to invest this forgotten word with a special significance or value.

According to Gregory Freidin (1987: 203), Mandel'shtam, under the influence of the Russian religious philosophers of the Silver Age, such as Sergei Bulgakov and Pavel Florensky, is lamenting the loss of the magic word, the true name that contains the essence of the thing named, the name endowed with mystical powers: "A mere memory slip is amplified on a hyperbolic scale, becoming the loss of that one and only word, the chthonic 'open sesame,' the password to rebirth and immortality." Kiril Taranovsky and Ronen treat "the forgotten word" as the word of poetry and hence the psychological process described in the poem as that of poetic composition: "There can be no doubt that Mandel'shtam's 'forgotten word' is the poetic word" (Taranovsky 1976: 78); "the finding of the poetic word becomes an act of anamnesis in the Platonic sense" (Ronen 1977: 177).

But the tip-of-the-tongue state is a mundane nuisance that may happen to anyone (not just to a poet) and with any word. In my view, Mandel'shtam is describing a commonrather than a mystical or poetic-experience along with the universal cognitive mechanism behind it. 
idiom for referring to this tip-of-the-tongue state. When people forget a word, they say vyletelo iz golovy: literally, "[it] flew out of my head."

The rest of the poem details the futile attempts to recall the word and employs terms surprisingly similar to those used in one of the earliest descriptions of the tip-of-the-tongue state by William James (1890, 1:251) in his Principles of Psychology:

The state of our consciousness is peculiar. There is a gap therein; but no mere gap. It is a gap that is intensely active. A sort of wraith of a name is in it, beckoning us in a given direction, making us at moments tingle with the sense of our closeness, and then letting us sink back without the longed-for term. If wrong names are proposed to us, this singularly definite gap acts immediately so as to negate them. They do not fit into its mould. And the gap of one word does not feel like the gap of another, all empty of content as both might seem necessarily to be when described as gaps.

Mandel'shtam's metaphorical description and James's scholarly one were of course written quite independently of one another, but James's "wraith of a name" bears a striking resemblance to Mandel'shtam's metaphors of shadow (chertog tenei, "palace of shades"), transparency (s prozrachnymi igrat', "to play with the transparent ones"), and incorporeality (mysl' besplotnaia, "unbodied thought"). This similarity accords with the feeling and intuition shared by anyone who has experienced this tip-of-the-tongue phenomenon. But the similarity goes beyond simple imagery: both Mandel'shtam and James describe the specifically cognitive characteristics of this state.

In modern cognitive research, the tip-of-the-tongue phenomenon is defined as "a momentary inability to utter an intended word, accompanied by the feeling that the target word is known and that it is on the verge of being available" (Miozzo and Caramazza 1997: 1411). The current cognitive explanation of tip-of-the-tongue states is based on a twostage model of speech production. "The selection of a word involves two stages: In Stage 1, a semantically and syntactically specified representation is accessed; in Stage 2, a phonological representation is accessed" (ibid.: 1410). The first-stage representation is designated as the lemma, the secondstage representation as the lexeme: lemmas and lexemes are interconnected (they constitute separate nodes in the neural network) but located in different zones of the brain. In normal speech production, lemmas and lexemes are activated at virtually the same time, and transmission from lemmas (i.e., syntactic and semantic representations) to lexemes (phonetic words) is immediate. The tip-of-the-tongue state results from a condition known as transmission deficit (the weakening of the neural connection between a lemma and a lexeme), which leads to a failure of phonological access: the 
lemma is accessed (i.e., we know the meaning and approximate syntactic "shape"), but the lexeme is unavailable (James and Burke 2000: 1378). ${ }^{14}$

Thus Mandel'shtam's poem can be easily translated into the language of modern cognitive neuroscience. The master metaphor is a familiar one: meaning (i.e., the lemma) is soul, and sound (i.e., the lexeme) is flesh. The incorporeal and transparent imagery stands for a lemma looking for its lexeme, its phonological embodiment, which would amount to the neural reconnection of the semantic and the phonological nodes: what Mandel'shtam calls "the rounded joy of recognition."

Both Mandel'shtam and James provide an accurate description of typical symptoms accompanying the tip-of-the-tongue state. The missing word seems very close to the surface, to the barrier blocking its retrieval. Again, in James's words, it is "beckoning us in a given direction, making us at moments tingle with the sense of our closeness, and then letting us sink back without the longed-for term." And in Mandel'shtam's:

И медленно растёт, как бы шатер иль храм,

То вдруг прикинется безумной Антигоной,

То мертвой ласточкой бросается к ногам

(And it swells slowly, like a tent or temple,

One moment suddenly pretends to be the crazed Antigone,

Lands at one's feet the next, like a dead swallow.)

James's spatial description of "beckoning," feeling "closeness," and then "sinking back" corresponds to Mandel'shtam's metaphor of the "slow swell" of a tent or (the cupola or dome) of a temple. The underlying image here is that of memory as a canvas sheet or sail (and by metaphorical extension, a tent or a dome) that is now swelled out by a gust of wind (the retrieval of the wrong word: "mad Antigone" or "dead swallow"), but then shrinks and collapses (realizing that the word is the wrong one). ${ }^{15}$

14. This is the currently accepted model: see, for example, Meyer and Bock 1992; Miozzo and Caramazza 1997; James and Burke 2000; Burke et al. 2004. See Brown 1991 and Schwartz 2002: 49-73 for reviews. For an alternative explanation, see Jones 1989; Jones and Langford 1987. See Schwartz 2002 for a general overview of the various aspects of tip-ofthe-tongue research.

15. This reading is supported by a comparison with the more explicit use of similar imagery in other Mandel'shtam poems. In a 1910 poem, "Slukh chutkii parus napriagaet," Mandel'shtam (1990, 1:71) uses the metaphor of a swelling sail for another cognitive phenomenon, namely, attentive hearing: "Слух чуткий парус напрягает, / Расширенный пустеет взор, / И тишину переплывает / Полночных птиц незвучный хор" (The attentive ear stretches out the sail, / The eyes grow empty from gazing into the distance, / And sailing over the silence / Goes a soundless choir of midnight birds). And in one of his 1933 "Octets," Mandel'shtam (ibid.: 201) provides an explicit description of a swelling and shrinking canvas sheet as a metaphor for the creative process: “Люблю появление ткани, / 
James's locutions ("beckoning," "making us at moments tingle") and Mandel'shtam's elusive word that keeps appearing in false guises ("one moment pretends" to be Antigone, the next-a dead swallow) reflect another important feature of the tip-of-the-tongue state: our memory provides us with various wrong alternatives. Both Mandel'shtam and James point this out and describe in detail the feeling of frustration and dissatisfaction that ensues. James continues the "gap" metaphor: "If wrong names are proposed to us, this singularly definite gap acts immediately so as to negate them. They do not fit into its mould."

Mandel'shtam is even more explicit and actually describes the insistent intrusion of wrong alternatives: "Vse ne o tom prozrachnaia tverdit" (The transparent [thought] keeps on repeating the wrong thing). In a variant of the last stanza, Mandel'shtam mentions another important characteristic of the tip of the tongue state-the lack of this word is torment:

А на губах как черный лёд горит

И мучит память: не хватает слова.

(But on the lips, like black ice, [it] burns

And torments memory: the word is lacking.)

Again, similar imagery can be found in scientific descriptions. Psychologists Roger Brown and David McNeill describe the feelings of their informant thus: "The signs of it [the tip-of-the-tongue phenomenon] were unmistakable; he would appear to be in 'mild torment,' something like the brink of a sneeze, and if he found the word his relief was considerable" (quoted in Schwartz 2002: 5). Thus Mandel'shtam's "Swallow" is indeed an elaborate exposition of the tip-of-the-tongue state. The poet's description is quite similar to those found in modern psychology: the connection between the lemma and the lexeme is lost, the word is on the verge of coming back to you, but instead, your memory is tormented by wrong alternatives. It is this last feature of the tip-of-the-tongue state - the appearance of the wrong alternatives - that is especially important for my present analysis.

Когда после двух или трех, / А то четырех задыханий / Прийдет выпрямительный вздох. / И так хорошо мне и тяжко, / Когда приближается миг, / И вдруг дуговая растяжка / Звучит в бормотаньях моих" (I love the look of the woven cloth, / When, after two or three, / Or maybe four labored gasps, / There comes a full free breath. / And I feel so good, so intense, / When the moment approaches, / And suddenly the sounds in my mutterings / Stretch and arc out). Here, as in "Swallow," the pulsation of the canvas stands for-at first unsuccessful-attempts to capture the word (or phrase). What is sought in "Octets," however, is not the "lost" word but the "right" word-the one that leads to an irruption of poetic energy. 


\section{A Horsey Name and a Beautiful Southern Tree}

Cognitive scientists observe that those who experience the tip-of-thetongue state are blocked from retrieving the word in two ways: they may remember alternate words that are semantically related to the target word (i.e., the semantic connections of the lemma are activated), or they may remember words that are phonetically related (the phonological connections of the lexeme are activated). Frequently, these two combine without producing the longed-for terms (Schwartz 2002: 3-6, 19-49).

Russian literature and folklore provide a convenient and colorful illustration of both semantic and phonetic retrieval strategies. Anton Pavlovich Chekhov's (1915 [1885]) hilarious short story "A Horsey Name" ("Loshadinaia Familiia") is built on wordplay with semantically related alternatives that block attempts to retrieve the missing word.

The plot involves a Major-General Buldeev, who is suffering from a monstrous toothache. His steward Ivan Evseich knows a certain znakhar'a healer who claims to have the magic power to remove pain. Ivan Evseich urges the general to send a telegram to this healer but cannot quite remember his name. All he remembers is that it had something to do with horses. "Just a minute! Jacob-Jacob-I can't remember it! It's a common name too, something to do with a horse. Is it Mayres? No it isn't Mayres - Wait a bit, is it Colt? No, it isn't Colt. I know perfectly well it's a horsey name, but it has absolutely gone out of my head!" (ibid.: 274). Soon the whole household is feverishly coming up with horsey names. That is, Ivan Evseich has given them a semantic clue (a name related to horses), and everyone is offering semantically related alternatives:

"It isn't Filley?"

"No, no - wait a jiffy. Maresfield, Maresden-Farrier-Harrier -"

"That's a doggy name, not a horsey one. Is it Foley?"

"No, no, it isn't Foley. Just a second-Horseman-Horsey-Hackney. No, it isn't any of those."

"Then how am I to send that telegram? Think a little harder!"

"One moment! Carter-Coltsford-Shafter-"

"Shaftsbury?" suggested the general's wife.

"No, no-Wheeler - no, that isn't it! I've forgotten it!"

... The steward went into the garden, and, raising his eyes to heaven, tried to remember the exciseman's name.

"Hunt-Hunter-Huntley. No, that's wrong! Cobb-Cobden-DobbinsMaresly-"

Shortly afterward, the steward was again summoned by his master. "Well, have you thought of it?" asked the general.

"No, not yet, your Excellency!" "Is it Barnes?" asked the general. "Is it Palfrey, by any chance?" 
Every one in the house began madly to invent names. Horses of every possible age, breed, and sex were considered; their names, hoofs, and harness were all thought of. People were frantically walking up and down in the house, garden, servants' quarters, and kitchen, all scratching their heads, and searching for the right name.

Suddenly the steward was sent for again. "Is it Herder?" they asked him. "Hocker? Hyde? Groome?"

"No, no, no," answered Ivan, and, casting up his eyes, he went on thinking aloud.

"Steed-Charger-Horsely-Harness-" "Papa!" cried a voice from the nursery. "Tracey! Bitter!"

The whole farm was now in an uproar. The impatient, agonised general promised five roubles to any one who would think of the right name, and a perfect mob began to follow Ivan [Evseich] about.

"Bayley!" They cried to him. "Trotter! Hackett!" (Ibid.: 275)

Finally the general, desperate for relief, sends for a real dentist. The latter arrives, pulls the tooth, and encounters Ivan Evseich on his way out. Ivan Evseich again is in what Brown and McNeill have called "mild torment" (in this case, perhaps not so mild) and what Mandel'shtam has also described as torment. "The steward was standing by the roadside plunged in thought, with his eyes fixed on the ground at his feet. Judging from the deep wrinkles that furrowed his brow, he was painfully racking his brains over something, and was muttering to himself: 'Dunn-Sadler-BuckleCoachman-"” (ibid.: 277). As he is leaving, the dentist offhandedly asks the steward about buying some oats - and suddenly Ivan Evseich recalls the lost name. It is Mr. Oates (Ovsov).

Thus in Chekhov's story the target word is a proper name-Mr. Oatesand all the alternatives proposed are semantically related to "something horsey."

Semantically Related Alternatives to "Mr. Oates" in Chekhov's "A Horsey Name"

\begin{tabular}{ll}
\hline Target word & Semantically related alternatives (blockers) \\
\hline Ovsov (Mr. Oates) & Mayres Colt Filley Maresfield Maresden Farrier Foley \\
& Horseman Horsey Hackney Carter Coltsford Shafter \\
& Shaftsbury Wheeler Hunt Hunter Huntley Cobb Cobden \\
& Dobbins Maresly Barnes Palfrey Herder Hocker Hyde \\
& Groome Steed Charger Horsely Harnes Tracey Bitter Bayley \\
& Trotter Hackett Gelder Dunn Sadler Buckle Coachman
\end{tabular}

A good illustration of phonetically related alternatives arising during a tip-of-the-tongue state is the following Russian joke. A Georgian man is staring at a beautiful southern tree trying to retrieve its name: 
Могу ли я? Не могу ли я . . Давно ли я ? Не давно ли я . . Говно ли я? Не говно ли я . . . О! Вспомнил! МАГНОЛИЯ!

(Am I able? No, not "Am I able" . . Has it been long since I? No, not "Has it been long since I" . . A Am I shit? No, not "Am I shit" . . Oh! Here it is: MAGNOLIA! $)^{16}$

The phonetic "blockers" of the forgotten word are what gives the joke its comic effect and double entendre. Mogu li ia? (am I able?) may imply impotence; davno li ia? (has it been long since?) may suggest something like how long has it been since I had sex; and govno li ia? (am I shit?) is self-evident. Another comic component is that the target word itself and all its alternatives end in $\ddot{i} a$, an ending typical of many Georgian surnames.

All three alternatives have the same syllable count and stress pattern (four syllables with a stress on the third) as the target word and support the psychologist Bennett L. Schwartz's (2002: 31-32) conclusions on phonetically related alternatives. In particular, Schwartz observes that phonetic alternatives often replicate the syllable count and stress pattern of the target word as well as its initial sounds (in our case, the stressed vowel $a$ and the consonants $m$ and $g$ ), consonant structure, and final syllables ( $l i-i a)$ in all three alternatives, just as in the target word.

Phonetically Related Alternatives in the "Magnolia" Joke

\begin{tabular}{ll}
\hline Target word & Phonetically related alternatives (blockers) \\
\hline МАГНОЛИЯ (MAGNOLIA) & {$[\mathrm{m} a-$ gù-li-ia] Могу ли я } \\
{$[$ mag-nò-li-ia $]$} & {$[\mathrm{d} a \mathrm{v}-n \grave{o}-l i-i a]$ Давно ли я } \\
& {$[\mathrm{g} a \mathrm{v}-n \grave{-}-l i-i a]$ Говно ли я }
\end{tabular}

Chekhov's story presents semantically related alternatives and the "Magnolia" joke phonetically related ones. In real life, however, when we experience this tip-of-the-tongue state, we tend to sort through both and ultimately use a combination of retrieval strategies.

Let us make a thought experiment and imagine a text, a poem, say, in which both strategies are at work. In such a poem, the target word would be formally absent but both semantically present (as a cross-section of semantically related alternatives) and phonetically present (in the coinciding sounds or syllables of the phonetically related alternatives). What I have just described is similar to Saussure's definition of an anagram - again, a phonetic reproduction within a poem of that poem's theme word. In the anagram, a hidden word (a proper name in most cases) is absent from

16. An imperfect literary translation of this obviously untranslatable joke might sound something like: "Mongolia . . . No, not 'Mongolia' . . By golly . . . No, not 'by golly' . . . Am I gooey . . . No, not 'am I gooey' . . Oh, here it is: Magnolia!" 
the text itself, but its presence is detectable and can be (re)constructed on the basis of phonetic and semantic clues: the phonetic elements of the name are dispersed throughout the line or passage that speaks about (or is addressed, ascribed, dedicated to) the bearer of that name. In the tip-ofthe-tongue state, the word (also very often a proper name) is hidden from the speaker but present in the speaker's memory-again, as a collection of phonetic and semantic clues. We have a residual phonetic image of the word echoed in the wrong phonetic alternatives at our disposal; we know what the word is supposed to mean and are able to retrieve its various semantic associations. Thus in reading this imaginary poem, the retrieval of the word on the tip of the poet's tongue and the decoding of the anagram will proceed in the same way: by finding a cross-section of semantic and phonetic alternatives.

I suggest that we have already encountered such an imaginary text, a poem that combines such for a missing word. It is Mandel'shtam's "Swallow," and we will now reread the poem, trying to remember the word that Mandel'shtam forgot, to retrieve it on the poet's behalf.

\section{Just What Word Did Mandel'shtam Forget?}

As we have seen, the basic plot of the poem is a description of a tip-of-thetongue situation. The imagery, however, is largely borrowed from Greek mythology. ${ }^{17}$ "Swallow" is one of three poems that make up Mandel'shtam's (1990, 1:130-32) Lethean Cycle, written in November 1920. All deal with the Greek kingdom of the dead. In the other two poems of the cycle, this theme is more explicit in that each makes specific reference to characters and situations found in the myths of the Greek underworld. Thus the first poem of the cycle, "Kogda Psikheia-zhizn' spuskaetsia k teniam" "When Psyche-life descends toward the shades"), describes Psyche as she follows Persephone down into the realm of shades; the third poem, "Voz'mi na radost' iz moikh ladonei" ("For your delight, take from the palms of my hands"), also mentions Persephone and refers to Charon's ferry and the river that separates the kingdom of the living from that of the dead.

Like the other two poems in the cycle, "Swallow" is built around imagery from the Greek underworld. The river Styx is mentioned twice: once in the third stanza ("with Stygian tenderness, with a green twig") and again in the last line ("The remembrance of the Stygian ringing"). Mandel'shtam

17. For a thorough analysis of the mythological subtexts in "Swallow" and in the Lethean Cycle as a whole, see Kovaleva 2005; Ronen 1977. For a more general overview of Mandel'shtam's use of classical themes, see Terras 1966; Przybylski 1966; Levinton 1977; Schlott 1981; Hesse 1989; Lekmanov 1995. 
also twice uses the phrase chertog tenei (palace of shades), which in Russian is a traditional periphrastic term for Hades.

To spare the reader further suspense, what I now propose to prove is that the forgotten word (or anagram) buried in Mandel'shtam's "Swallow" is in fact $\operatorname{Aid}$ (Hades). ${ }^{18}$

In addition to its overt mythological references to the Greek underworld, the poem (and the entire Lethean Cycle) may also contain a wordplay on the famous example of folk etymology: Hades in Greek is Allons, $A$-ides: alpha privativum (i.e., negation) plus $i d$, the root that signifies "to see"-that is, "un-seen," "in-visible," or "non-seeing." ${ }^{19}$ I suggest that Mandel'shtam might have poetically extended this etymology to imply "invisible because incorporeal" or "pellucid, see-through, transparent." This semantic development would not contradict the logic of the Greek myths, in which the inhabitants of Hades are pictured as fleshless, incorporeal shades or phantoms.

Mandel'shtam's creative re-etymologization may partly explain his peculiar insistence on the use of the epithet "transparent" (prozrachnyi) in describing the kingdom of the dead in "Swallow" and the other poems of the Lethean Cycle. As scholars have already noted (Osherov and Barsova 1995; Toporov 1995), he uses the adjective eight times in the three short poems that make up the cycle. In the cycle as a whole, transparency expresses the incorporeal, phantomlike aura of the underworld realities. In the first poem of the cycle, "Kogda Psikheia-zhizn' spuskaetsia k teniam"

18. Russian has two words derived from the Greek word Hades: ad, which is the more general and usually refers to the Judeo-Christian concept of "hell," and Aid (Hades), which is only used in the context of classical mythology and refers to the Greek underworld.

19. This etymology is mentioned in Plato's Cratylus (403A; 1998: 35), but Mandel'shtam is also likely to have read of it in Florensky's The Pillar and Ground of the Truth (1997 [1914]). We know that Mandel'shtam was an attentive and enthusiastic reader of Florensky's works: in her memoirs, Nadezhda Mandel'shtam (1970: 248) mentions that Florensky's Pillar was one of Osip Mandel'shtam's "book-satellites" and the only book he took with him when he traveled to Kiev in 1919. In Pillar, Florensky (1997 [1914]: 132-33) discusses the philosophical significance of the etymology in considerable detail:

Gehenna, sin, is darkness, absence of light, skotos. For light is the visible revelation of reality, while darkness is the isolatedness, the separatedness of reality. It is the impossibility of appearing to one another, mutual invisibility.

The very name for hell in Russian, $A d$, from Hades, points to such a gehennal rupture. . . . In fact, the Greek Hades, Haides, or Aides (originally AFides) comes from the root Fid (= the Russian vid), which forms the verb id-ein, in Russian vid-et' (to see), and the particle of negation, or rather privation, the a privativum. $A d$ [Hades] is a state of invisibility, which one does not see and where one does not see. $A d$ is a state of non-seeing (bez-vid).

As is the case with many Platonic etymologies, this one had long been considered too poetic to be true. However, it has recently been reevaluated (see Beekes 1998) and is now regarded as the most reliable (Ivanov 1999). 
("When Psyche-life descends toward the shades"), Psyche finds herself in the "semitransparent forest" (poluprozrachnyi les) and "does not recognize the transparent groves" (ne uznaet prozrachnye dubravy). She is surrounded by other souls who address her with laments in a "leafless forest of transparent voices" (les bezlistvennyi prozrachnykh golosov). In "Swallow," the underworld night is inhabited by horses with "transparent manes," while the image of the transparent forest reappears in the third poem of the cycle, "Voz'mi na radost' iz moikh ladonei" ("For your delight, take from the palms of my hands"): the bees of Persephone, the goddess of the dead, "shurshat v prozrachnykh debrakh nochi" (rustle in the transparent thickets of the night). This epithet is used twice more in "Swallow" to emphasize the poem's focal image, the forgotten word, a semantic blob bereft of its phonetic materiality. In the first stanza, the poet tells us that the forgotten word - the blind swallow - "will return . . . to play with the transparent ones" (s prozrachnymi igrat'), namely, other unrealized words. And in the last stanza, "the transparent [thought]" - that is, the forgotten word- "keeps on repeating the wrong thing" (Vse ne o tom prozrachnaia tverdit), as if looking for its phonetic flesh. ${ }^{20}$

One could also interpret A-ides as "non-seeing," that is, blind. This may explain the image of the "blind swallow" in the first stanza and clarify the seemingly obscure imagery of the fourth stanza: "O esli by vernut' I zriachikh pal'tsev styd, / I vypukliuiu radost' uznavaniia" (O, if I could bring back the shame of seeing fingers / And the rounded joy of recognition). The metaphor here is based on the image of a blind man (perhaps Oedipus, accompanied by his daughter Antigone, twice mentioned in the poem) who can recognize - and thus "see" - a familiar face by physically touching its rounded (or, literally, convex [yypukluiu]) shapes. This recognition, shameful (because relegated to the tactile) $)^{21}$ but still joyful, is now impos-

20. Further evidence for Mandel'shtam's (1990, 1:112) association of transparency with Hades may be found in the 1916 poem "V Petropole prozrachnom my umrem," where the poet's native city of Saint Petersburg (called "Petropolis" in the poem) is described as the kingdom of the dead ruled by Proserpine (Persephone): "V Petropole prozrachnom my umrem, / Gde vlastvuet nad nami Prozerpina" (We will die in transparent Petropolis / Where Proserpine reigns over us). See Osherov and Barsova (1995: 197-98) on the epithet "transparent" (prozrachnyi) as a recurrent attribute of the netherworld in Mandel'shtam's poetry of the 1920 s. 21. Another intertextual connection may clarify Mandel'shtam's use of the word "shame" in this line. "Seeing fingers" is likely to be an allusion to "the seeing hand" in Goethe's (1964: 95-96) erotically charged Roman Elegy V: "Aber die Nächte hindurch hält Amor mich anders beschäftigt; / Werd ich auch halb nur gelehrt, bin ich doch doppelt beglückt. / Und belehr ich mich nicht, indem ich des lieblichen Busens / Formen spähe, die Hand leite die Hüften hinab? / Dann versteh ich den Marmor erst recht: ich denk und vergleiche, / Sehe mit fühlendem Aug, fühle mit sehender Hand" (But throughout the nights Cupid [Amor] keeps me busy in another way; / I become only half a scholar, but twice as happy. / And is 
sible, because the word is lost and bereft of materiality: one can hardly see it (because of its transparency) or even touch it. This reading might seem forced if it were not for Mandel'shtam's (1979: 115-16) own much more explicit treatment of the same imagery in his essay "The Word and Culture," written a year after "Swallow," in 1921: "Write imageless verse if you can, if you are able. A blind man recognizes a beloved face by barely touching it with seeing fingers, and tears of joy, the true joy of recognition, will fall from his eyes after a long separation." As so often in Mandel'shtam, his prose serves as an auto-commentary, dealing with the same images as in poems written during the same period but clarifying them and filling out the lacunae of the poetic diction. In the essay, Mandel'shtam puts the metaphor in a different context: a poem without (visual) images can still be a great poem and will be recognized as such by a good reader, the way the blind man recognizes a familiar face. However, the conceptual structure of the metaphor and the key images remain the same. Note the literal coincidences: "the shame of seeing fingers," "the rounded joy of recognition" ("Swallow") / "touching it with seeing fingers," "true joy of recognition" ("The Word and Culture").

Thus the semantic arguments in favor of the hypothesis that the target anagrammatic word (or the word Mandel'shtam wanted to say) in this poem is Aid (Hades) are as follows:

(1) On the level of plot and imagery, the Lethean Cycle as a whole deals mainly with the mythology of the Greek underworld, Hades and various manifestations of the popular classical motif of catabasis (descent to the underworld). The poems of the cycle refer to Persephone, the myth of Psyche descending to the shades, Antigone burying her brothers, the shadows inhabiting Hades, and Charon's ferry. In particular, in "Swallow" the epithet "Stygian," related to the mythological river Styx that laves Hades, is also repeated twice: "S stigiiskoi

this not learning, to study the forms of her lovely bosom, / and slide my hands down over her hips? / For I understand marble then all the better: I reflect and compare, / See with a feeling eye, feel with a seeing hand) (translation by David Luke, modified). The parallel is supported by the fact that Mandel'shtam, who was an attentive and enthusiastic reader of Goethe throughout his life, returns to this same passage in a short poem from 1935, "Rimskikh nochei polnovesnye slitki" (1990, 1:220): "Rimskikh nochei polnovesnye slitki, / iunoshu Gete manivshee lono" (Full-weight ingots of Roman nights, / the breasts that tempted young Goethe). Thus in addition to the hands of a blind man, "the shame of seeing fingers" may refer - through Goethe - to a lover's hypersensitive, tactile perception of the beloved's body. Nadezhda Mandel'shtam (1974: 543), the poet's wife, provides a biographical context for this image in a commentary on the poem included in her memoirs: "The rounded joy of recognition'-just what he [Osip Mandel'shtam] experienced when he passed his hand over my face. This was the essence of the sense of touch - 'rounded joy,' the skin's capacity to perceive, see, and feel." 
nezhnost'iu i vetkoiu zelenoi" (With Stygian tenderness and a green branch) in the third stanza; "Stigiiskogo vospominan'e zvona" (The remembrance of Stygian ringing) in the last stanza.

(2) In the poem "Swallow," the Russian poetic periphrasis of Hades, chertog tenei (palace of shades) is repeated twice: "Slepaia lastochka $\mathrm{v}$ chertog tenei vernetsia" (The blind swallow will return to the palace of shades) in the first stanza and "Mysl' besplotnaia v chertog tenei vernetsia" (The unbodied thought will return to the palace of shades).

(3) Finally, the word Aid (Hades), from the Greek Aides, manifests itself in the epithets "blind" and "transparent": the two possible interpretations of the folk etymology of this word.

On the phonological level, the clues to the word Aid (Hades) are omnipresent throughout the poem. The word Aid consists of just two syllables, $a$ and $i t / i d,{ }^{22}$ both of which are extremely common in Russian. So the mere fact that they are frequently found in "Swallow" is no proof of the elusive word. However, the combination of $a$ and a stressed $i t / i d$ is peculiarly persistent in this poem and its variants:

пальцев стьљ [pal'tsef styt] = [a-yt] (stanza 4, line 1); ръцданья аонид [ridan'ia $a a$ n $i t]=[\mathrm{id}-\mathrm{a}-\mathrm{a}-\mathrm{it}] \quad(4,3)$;

прозрачная твердит [prazrachnaja tv'ird'it] = [a-it] $(6,1)$; горum [garit $]=$ [a-it]; само гудит [samo gud'it] $=[\mathrm{a}-\mathrm{it}] \quad(6,3)$.

The word $A u d$ in its correct orthographic form can be read in the fourth stanza, third line, in the word $а$ онид.

More convincing proof, however, is the fact that these syllables are placed at the end of lines. The word Aid (Hades), phonetically [ait], is left unsaid, while its sound pattern [a-it], with a stress on the second syllable [it], constitutes the rhyme to four lines in the poem and two more in the variant of the last stanza, all ending in the stressed [it]. The rhyming words are styd [styt] (stanza 4, line 1), aonid [aon'it] $(4,3)$, tverdit [tv'ird'it] $(6,1)$, gorit [gar'it] $(6,3)$, gorit [gar'it] (variant of 6,1$)$, and gudit [gud'it] (variant of 6,3$)$. Thus the chain of rhymes would seem to provoke the reader into complementing it with another rhyming word, Aid [ait] (Hades) - also suggested, as shown above, by the plot and imagery of the poem.

This peculiar anagrammatic device is one that Mandel'shtam used

22. The Russian phoneme $i$ stands for two allophones: the frontal vowel [i] after palatalized consonants and the back vowel [y] after hard ones. The phoneme $d$ also stands for two allophones: voiceless $[\mathrm{t}]$ and voiced [d]. It is pronounced [d] before a vowel and [t] at the end of the word or before another voiceless consonant. Thus the pronunciation of the word Aid (Аид) in the nominative, followed by the zero ending, is [ait], but in the oblique cases, followed by vocalic case endings, it is pronounced [aida] (genitive), [aidu] (dative), etc. 
elsewhere. ${ }^{23}$ One may cite the evidence of the poet's wife, Nadezhda Mandel'shtam (1970: 204), about a similar poetic mechanism at work in the fourth stanza of Mandel'shtam's 1935 poem "Stansy" ("Stanzas"):

В семивершковой я метался кутерьме:

Клевещущих козлов не досмотрел я драки, Как петушок в прозрачной летней тьме,Харчи, да харк, да что-нибудь, да вракиСтук дятла сбросил с плеч. Прыжок. И я в уме.

(Mandel'shtam 1990, 1:217)

(In a seven-inch commotion I rushed about:

I didn't stick around for the brawls of the slandering goats,

Like a cockerel in the transparent summer darkness,-

Grub, and phlegm, and something, and a passel of fibs -

[I] shrugged off my shoulders the woodpecker's hammering. A leap. And I'm back in my right mind.)

(Translated by Penny Burt)

This passage reveals the tortured state of the poet's mind toward the end of his stay at a hospital in Cherdyn' in the northern Urals, where he was exiled for writing an anti-Stalin poem. "A leap" in the last line refers to Mandel'shtam's attempt to commit suicide by jumping out of a hospital window (Lekmanov 2003: 179; Dutli 2005: 288). This biographical detail helps elucidate the stanza's highly condensed, elliptical imagery as a snapshot of what surrounded the poet in the ward in the moment immediately preceding the suicide attempt. He rushes about in a dirty and cramped room ("like a cockerel"), witnesses a brawl among patients ("slandering goats"), faces a blurry jumble of the oppressive details of hospital life ("grub, and phlegm, and something") and meaningless petty talk ("passel of fibs"). All of these impressions merge into an unbearable mental torture ("the woodpecker hammering" on his shoulders), with the only way outand back to sanity - being the suicidal leap.

23. John Shoptaw (2000: 225) calls this poetic device a phonemic cryptography and analyzes the following example from Shakespeare:

In Sonnet 48 Shakespeare hides the addressee from himself:

Thee have I not locked up in any chest,

Save where thou art not, though I feel thou art,

Within the gentle closure of my breast,

From whence at pleasure thou mayst come and part.

The repeated "art" audibly marks the barely concealed crypt word, heart; the correlative figure of the beloved as a valuable treasure is also marked by "pleasure." (Note that though "art" and "pleasure" both rhyme with their crypt words, they are not foregrounded as intentional puns.)

(For a discussion of this device in Mandel'shtam, see Cavanagh 1995: 175.) 
Mandel'shtam's forced stay at the hospital, for all intents and purposes, amounted to imprisonment, and the poet perceived it as such. According to Nadezhda Mandel'shtam, the phrase "in prison" (v tiur'me) is actually hidden within this stanza as a potential rhyme, complementing the chain of rhymes in the first, third, and fifth lines of the stanza: "in prison" (v tiur'me), absent from the text, does in fact rhyme with $v \ldots$ kuter'me (commotion) -t'me (darkness) -v ume (in mind).

Another impressive instance of the anagrammatic use of a "concealed" rhyme is found in Mandel'shtam's "Oda k Stalinu" ("Ode to Stalin"), written in 1937 in the vain hope of appealing to the tyrant's indulgence. Under the imminent threat of further punishments, Mandel'shtam attempted to save himself by producing a poem that would demonstrate his loyalty to Joseph Stalin and the official ideology. This ode includes a conspicuously flattering account of Stalin's political biography and ends with a stanza that contains Stalin's name without naming it:

Правдивей правды нет, чем искренность бойца
Для чести и любви, для доблести и стали,
Есть имя славное для сжатых губ чтеца,
Его мы слышали, и мы его застали.

(Mandel'shtam 1990, 1:433)

(No truer truth exists than a warrior's sincerity:

For honor and love, for valor and steel [stali],

There is a glorious name made for the taut lips of a rhapsode-

We've heard it, we lived to see him.)

(Translated by Gregory Freidin [1987: 260] ${ }^{24}$

Here the device is laid bare, since Mandel'shtam explicitly refers to the process of pronouncing Stalin's name, "Est' imia slavnoe dlia szhatykh gub chtetsa" (There is a glorious name made for the taut lips of a rhapsode), and then leaves out the name - which is nonetheless easy to guess because of the rhyme pattern: "stali" (steel) in the second line and "zastali" (lived to see [him]) in the third.

The last stanza of "Swallow" also mentions lips which still keep the articulatory memory of a word, and the unnamed word Aid also manifests itself as a concealed rhyme to two lines of the stanza.

Bсё не о том прозрачная твердит (tverdit),

Всё ласточка, подружка, Антигона . . .

И на губах, как черный лед, горит (gorit)

Стигийского воспоминанье звона.

24. On the paronomastic play on Stalin's name in the "Ode to Stalin," see Freidin 1982: 416; Brinkley 2003: 45 . 
(The transparent [thought] keeps on repeating the wrong thing, Again and again: swallow, friend, Antigone ...

But on the lips, like black ice, burns

The remembrance of Stygian ringing.)

Phonetic Indications of the Word Aid (Hades) in Mandel'shtam's "Swallow"

\begin{tabular}{ll}
\hline Target word (anagram) & Phonetic indications of the word Aid [a-it] in the text \\
\hline АИД (HADES) & 1) Syllables [a] and [it] in proximity: \\
{$[a-i t]$} & пальцев стыд [pal'tsev stit] \\
& аонид [aon'it] \\
& прозрачная твердиm [prazrachnaja tv'ird'it] \\
& горит [garit] \\
& само гудит [samo gud'it] \\
& 2) Concealed rhyme: \\
& styd [stit] (stanza 4, line 1$)$ \\
& aonid [aon'it] $(4,3)$ \\
& tverdit [tv'ird'it] $(6,1)$ \\
& gorit [gar'it] $(6,3)$ \\
& gorit [gar'it] (variant of 6,1$)$ \\
& gudit [gud'it] (variant of 6,3$)$
\end{tabular}

Thus it is very likely that Mandel'shtam did weave the word Aid (Hades) into both the semantic and the phonetic fabric of the poem. Is this hidden word (this anagram), this unsaid word, an example of a tip-of-the-tongue state that really occurred to Mandel'shtam? We will never know for sure. The failure to retrieve the word Aid (Hades) might have initiated a train of images and sounds that eventually led to the poem. Or the idea of hiding the word Aid (Hades) in an anagram might have come to him as he was reading the passage in Plato's (1998: 35) Cratylus (403A), where both the folk etymology and the tabooistic use of the word are invoked: "It seems to me that most people call him [the god] by the name 'Pluto', because they are afraid of what they can't see (aeides), and they assume that his other name, 'Hades', associates him with that [i.e., what they can't see]." But regardless of whether Mandel'shtam did in fact forget the word Aid (Hades), one thing is clear: the cognitive structure of the Saussurean anagram is close to that of the tip-of-the-tongue phenomenon. In hiding a word, the anagram may follow the rules we employ when we are trying to retrieve one.

\section{On the Tip of the Mind: Anagram as Priming}

The similarities between the anagram and the tip-of-the-tongue state may be due to the fact that they both depend on the psychological phenomenon 
known as priming. Priming is a type of implicit (i.e., nonconscious) memory which facilitates reaction to a stimulus (the "target") that is identical, similar, or related to a previously encountered stimulus (the "prime").

The interest in priming was initiated by a classic experiment by David E. Meyer and Roger W. Schvaneveldt (1971; see Neely 1991 and McNamara 2005 for a review of the vast literature on priming). In this experiment, the subjects were shown cards with pairs of words in three combinations: either two existing words that are semantically related (nurse/doctor), or two existing unrelated words (bread/doctor), or one nonce word and one real word (marb/bread). The task was to identify the pairs either as both real words or not. The surprising result was that it took subjects significantly less time (eighty-five milliseconds on average) to identify a pair as "two real words" if the words were related. The implication is that the encounter with the word nurse primes the word doctor: that is, makes the target word (doctor) more available for processing and thus facilitates recognition. This phenomenon is now known as semantic priming.

A similar effect is achieved by prior processing of stimuli (e.g., pictures or words) that are perceptually related to the target stimulus: for example, to one that contains similar visual features or shares one or more syllables or the same initial consonant. This facilitation of recognition by perceptually related stimuli is called perceptual priming.

Thousands of experiments on various aspects of both semantic and perceptual priming have been conducted over the last decades, but the experimental paradigm in all priming-related studies has, for the most part, remained the same as in the original 1971 article: a priming effect is said to occur when the mere exposure to a prime speeds up the processing of a target that is either identical or in some way related to the prime. A short excursus into the psycholinguistics of priming may clarify the relations between the anagram and the tip-of-the-tongue state.

Most current psycholinguistic models represent speech production as the sequential top-down activation of nodes, first in the semantic, then in the lexical/syntactic, and finally in the phonological networks. In such models, priming is considered "a form of subthreshhold activation that prepares a node for activation or retrieval" (James and Burke 2000: 1379). In other words, in normal speech production, while most of the activation affects the nodes leading to the "needed" word, it also spreads to the neighboring nodes and partly activates them as well. For example, when we are gearing up to pronounce the word doctor, we partly activate words that share its semantic nodes (such as "being related to medicine") and phonological nodes (such as the syllables [doc] and [tor], or its phonemes, or its syllabic structure). 
This brings us back to the tip-of-the-tongue phenomenon. As mentioned before, it is usually explained as a deficit in the transmission between semantic and phonological representations. According to this-currently generally accepted-hypothesis, the persistent wrong alternatives that we sort through while trying to retrieve the lost word result from priming: the available nodes of the word on the tip of the tongue activate its semantic and phonological neighbors. A competing account of the tip-of-the-tongue phenomenon argues that these persistent alternatives are not the result but the cause of tip-of-the-tongue states: the primed words "overwhelm" the target word because of a deficit in inhibition, that is, the impossibility of suppressing the other connections that are activated along with those of the target word. The inhibition deficit hypothesis is intuitively convincing (we do feel that the persistent alternatives hinder the correct retrieval) but seems to contradict the sequential model of activation. In order to resolve this debate, psychologists Lori E. James and Deborah M. Burke (2000) came up with an ingenious experiment. They postulated that if transmission deficit is responsible for the tip-of-the-tongue state, then prior priming of the target word will either prevent the tip of the tongue from happening or facilitate its resolution, because the nodes of the targeted word will receive additional activation from the primes. If, however, an inhibition deficit is at fault, then primes will add to the confusion and lead to more tips of the tongues. To induce tip-of-the-tongue states for experimental purposes, the usual procedure is to ask the subjects general knowledge questions about low frequency words or to show pictures of famous persons and ask for their names. Since low frequency words and proper names have less developed semantic networks, they are more likely candidates for inducing tip-of-the-tongue states.

James and Burke presented subjects with a series of such general knowledge questions on computer screens preceded by a list of words, some of which - without the knowledge of the subjects - contained syllables of the target word (i.e., the answer to the general knowledge question). The priming words on this list were mixed with filler words to prevent the subjects from detecting the connection between the prime and the target. The subjects were asked to read the words and rate their pronunciation difficulty: again, to mislead them about the real nature of the task. They were then presented with the "tip-of-the-tongue inducing question." Figure 1 demonstrates the structure of the experiment.

I hope that this figure has by now primed in the reader's mind the central topic of the present article, the Saussurian anagram. Indeed, the structure of the anagram is similar to what James and Burke presented to their subjects. In their experiment, the target word is hinted at by the syllables 


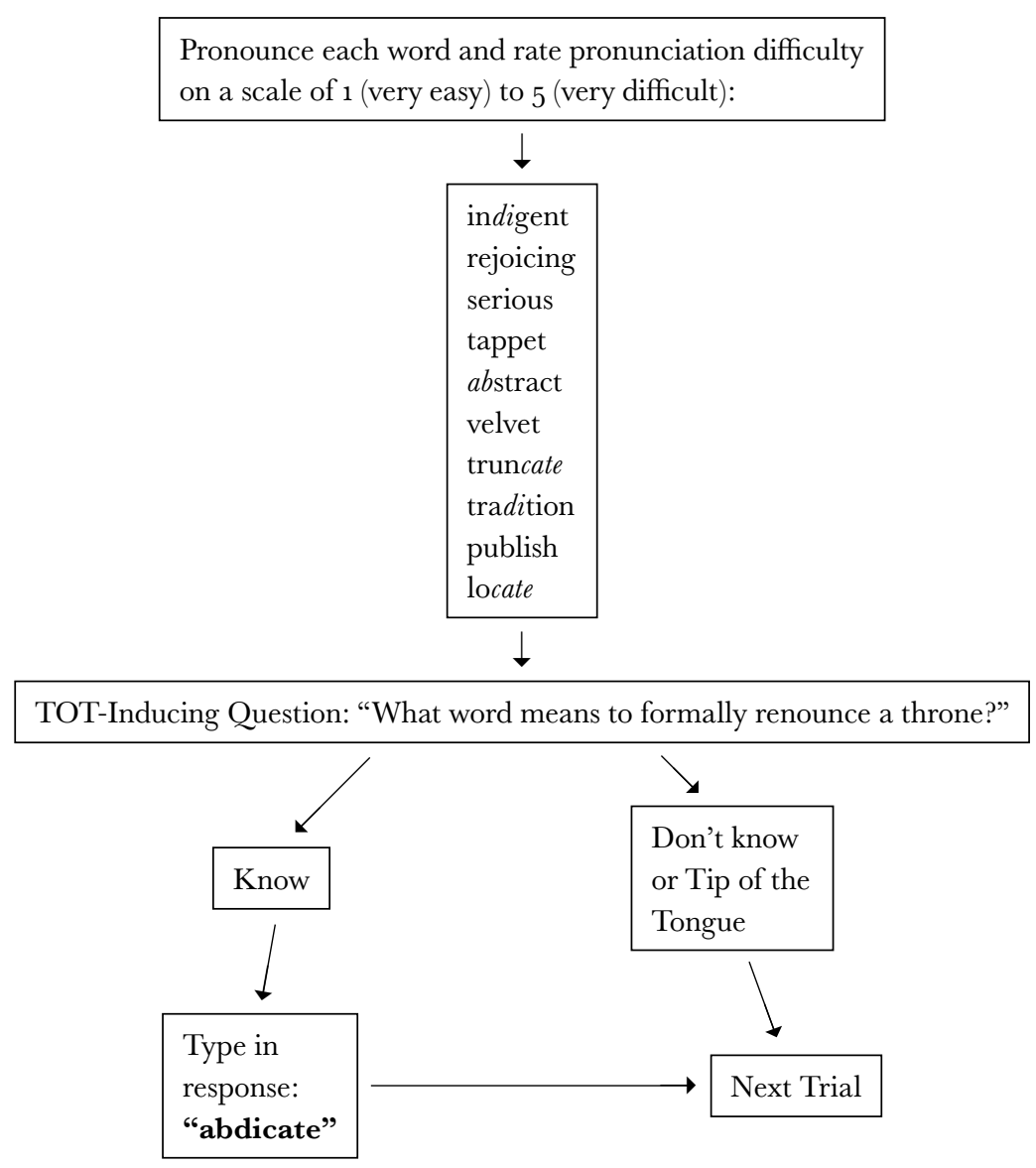

Figure 1 An example of the presentation of the general knowledge question and processing task in the James and Burke (2000: 1382, figure 2) tip-of-the-tongue experiment. (The syllables shared with the target word were not underlined in the experiment.)

shared with the words on the list, just as, in the anagram, the syllables of the theme word are dispersed within the words of a poetic line. The experiment's general knowledge question provides a strong semantic cue, analogous to the semantic indicators of the "hidden" theme word in the anagram. Granted, a psychological experiment and a poetic device are obviously quite different, but the structural analogy is close enough to suggest that the results of this experiment have implications for the anagram as well.

In fact, the results of the experiment confirmed the transmission deficit hypothesis: exposure to phonologically related words reduced the number 
of tip-of-the-tongue states or facilitated their resolution. In other words, the phonologically related words helped activate the target in the subjects' memory-prevented it from slipping into what Mandel'shtam called "the palace of shadows," the netherworld of oblivion.

The analogy between this experiment and Saussure's anagram may shed light on the anagram's cognitive nature and function. I suggest that the anagram may in fact be a manifestation of perceptual and semantic priming and may therefore provide a mnemonic support for a poetic utterance. The anagrammatic word (the theme word in Saussure's terminology) serves as a powerful prime that sends waves of activation throughout its semantic and phonological networks and makes its phonological and semantic "neighbors" more available to a poet during the creative process, thus helping these words emerge and reach the surface of the linguistic consciousness.

The need to "hide" the word would make this process especially pronounced by keeping the prime in the poet's consciousness and/or subconsciousness - on the tip of his or her mind, so to speak. Historically, such a need may have arisen, as Saussure suggested, in the context of religious and necrologic poetry: taboos on the proper names of deities and of the deceased have been attested in many religious traditions. Another possible context where the poet may feel the need to conceal the name of the addressee is love poetry - which, after all, constitutes a good chunk of all existing verse. One may safely assume that in many poetic traditions poets do not necessarily want to broadcast the names of their beloved to the reading (or listening) public. Finally, the poet's own name, his or her signature, is another proper name that is bound to be active in the poet's consciousness but may not explicitly appear in his or her poems.

Saussure and his followers have found numerous anagrams stemming from these three types of proper name avoidance. Such situations would press for priming, but any proper name (or any word) that is active enough in the poet's memory at the time of composition may, in theory, lead to priming effects.

If priming explains the cognitive mechanism of the anagram, its mnemonic properties may shed light on the anagram's function. The mnemopoetic approach advocated here regards any successful poem as an elaborate mnemonic device, designed to capture and reinforce a fragment of the poet's lived or mental experience and then to embed it in the readers' memory. In this view, some of the most basic structural elements of verse are, in essence, memory aids. Rhyme, meter, alliteration, and recurrent formulas have been shown to ease the burden of memory by imposing various constraints on a potentially limitless number of possible word choices 
(see Rubin 1995). Note that the mechanism underlying these constraints is, again, priming. Rhyme, for example, is a prime: experiments have shown that exposure to a word primes in our memory the words that rhyme with it and therefore makes them more available for eventual retrieval in the recitation of a poem (Montant and Ziegler 2001; Slowiaczek 2000). The anagram functions in a similar way. We have seen that the experiment of James and Burke shows that a pattern similar to the Saussurian anagram wards off tip-of-the-tongue frustration and leads to the improved recognition and retention of the target word. Since priming, by definition, is bidirectional (i.e., related stimuli prime each other), one may assume that when the situation is reversed-when the target word is made primethis target word will then activate, and thus cement in memory, the words that share its phonological and semantic nodes. As rhyme limits possible word choices by providing a phonological clue, so too the anagrammatic word puts some-although obviously weaker-constraints on the multitude of verbal choices and thus helps keep them in the memory. But whose memory?

\section{Memorable Speech}

Still, the analogy between rhyme and the anagram may seem misconceived. Rhyme is a highly perceptible device immediately available to the reader, whose memory then uses the rhyme as an aid in reproducing the text. The anagram, however - at least in the majority of observed instances - is hidden from the common reader and has to be detected by a scholar. Therefore, as distinct from rhyme, it should play no role in the mnemonic transmission and circulation of the poem. But if not the reader, who is then the beneficiary of the mnemonic facilitation afforded by the anagrammatic pattern? In my opinion, it is the poet.

One of the basic premises of the mnemopoetic approach is that the advent of writing did not put an end to the oral mode of poetry's existence, which continues to play an important part in most poetic traditions in the form of the mnemonic circulation of poetry (e.g., poetry memorization and recitation). But this oral mode also informs the ways poems have been created: the mnemonic reader of poetry-one who recites or cites-needs a mnemonically efficient poem, "memorable speech." And in order to fit the channels of mnemonic transmission, such a poem has to be composed mnemonically, in the poet's head rather than on paper, through a process of internal mnemonic elaboration.

A detailed substantiation of the claim that the mnemonic mode of poetic composition has been widespread and is still in use would require a sepa- 
rate study. Here I will limit myself to evidence from the poetic practice of Mandel'shtam, a mnemonic poet par excellence. His poems are among the most known by heart in today's Russia, and their memorability, in my opinion, stems from the way Mandel'shtam composed. We are lucky to have a fairly detailed account of Mandel'shtam's creative process in the memoirs of his wife, Nadezhda Mandel'shtam (1974: 477-78), who throughout their life together doubled as the poet's first reader, critic, and editor-and as the recorder of his poems, for Osip Mandel'shtam rarely bothered to write them down himself:

M. [Mandel'shtam] even boasted that he never wrote at all, working only with his voice. . . If ever he made a fair copy of a poem, it was usually not to keep but to give to someone who had asked for an autograph. This quite often happened when he was still at work on the poem, before it had taken final shape, so that these neat, autograph copies do not represent the end product. The final versions were generally taken down by me to his dictations. As he dictated, he always grumbled because I could not at once memorize the whole poem at first hearing. ...

M. just failed to understand why I could not remember a poem he already had in his head.

Two important characteristics of mnemonic creativity are documented in this passage. First, it highlights the priority of the oral mode of composition, while writing it all down on paper serves as a secondary and optional medium. The "boast" in the first line of the passage is a reference to Mandel'shtam's Fourth Prose, a magnificently eloquent diatribe against official Soviet writers. There Mandel'shtam (1997 [1909]: 197) proudly declares that the ability to compose orally ("with his voice") is the hallmark of a true poet, thus separating himself from the lowly breed of writers in the most basic sense of the word - those who write: "I have no manuscripts, no notebooks, no archives. I have no handwriting, for I never write. I, alone in Russia, work with my voice, while all around me consummate swine are writing. What the hell kind of writer am I? Get out, you idiots!" In the present context, it is worth noting that the Mandel'shtams considered it too risky to keep the manuscript of Fourth Prose at home, and the text only survived the period of Stalin's purges because Nadezhda Mandel'shtam committed this rather lengthy $(3,362$ words, to be exact) essay to memory and was able to reproduce it verbatim in the sixties.

Second, Osip Mandel'shtam's insistence that his wife internalize the poem "at once, at the first hearing" illustrates what may be termed the principle of mnemonic transitivity: whatever is composed mnemonically is designed - and expected - to travel effortlessly into other people's memory. Elsewhere in her memoirs, Nadezhda Mandel'shtam gives an account 
of the creative process that results in such mnemonic poems. Note that in the following passage she is describing not just her husband but a generalized "poet," because her analysis draws on a lifetime of observing other great Russian Silver Age poets with whom she kept company: first of all, Anna Akhmatova, a close friend of the Mandel'shtams and another mnemonic poet, who, according to the memoirist, "only started using notebooks in her old age" (Mandel'shtam 1974: 477), and probably also Nikolai Gumilev and Velimir Khelbnikov.

A poet's memory is always unbelievably overloaded, even if he is the kind who writes down his verse straightaway and keeps the drafts. But before the draft stage, that is, even before the poem has taken shape-or is only in the process of doing so-there is a lengthy period of preparation which goes on only in the mind, and none of this gets onto paper. During this period words and combinations of words are marshaled in the poet's head, together with lines or even whole stanzas that have still not fallen into place, or in which no idea has formed or-as is more frequently the case-exists only in embryo. Such lines and stanzas sometimes go into a later poem, or prompt the appearance of a new one. In themselves they are mere raw material and may linger in the mind for years before suddenly surfacing to be allied with the new material. Even in periods of apparent silence or rest, a poet is still at work mentally preparing his stocks of raw material. (Ibid.: 391)

Her use of general terms notwithstanding, there is no way to verify the universality of Nadezhda Mandel'shtam's observations. They may fully apply to Osip Mandel'shtam's and Akhmatova's "paperless" poetic practice but perhaps less so to less mnemonic poets, the ones "who write down [their] verse straightaway." Still, to the extent that Nadezhda Mandel'shtam's account represents the psychological reality of at least one (in my opinion, very common) kind of creative process, it confirms the mnemopoetic view of poetic creativity. The mnemonic poet "marshals in his head," combines and recombines potential fragments ("words and combinations of words") of the poem in the making, and constantly revisits them in order to build upon them, to leave them aside for future use, or to discard them. A fragment in its more or less final shape has to "stay put" in the poet's mind and therefore must be constantly refreshed or else risk being dissipated into oblivion under the pressure of the limitations of short-term memory. New "embryonic" fragments are measured mnemonically against the existing ones - and may well end up transforming or replacing them altogether. During these periods of gestation (which may go on for years or condense into a few hours of poetic inspiration), these would-be pieces of a future poem are engaged in a fierce battle for mnemonic survival-and this is where the anagram, along with other semantic and phonetic constraints, 
comes in handy. An anagram provides a fragment with mnemonic support, thus making it more "fit" and likelier to survive (i.e., to remain in the final version of the poem).

Under normal speech conditions, the ultimate concern of the speaker is to pass on information, and that is how we measure the effectiveness of an utterance. Once this information has been transmitted, the utterance is no longer needed. Poetic speech is concerned with the durability of the utterance itself, and in order to be ready for a long mnemonic journey outside the poet's consciousness, it has first to withstand a mnemonic test inside the poet's head.

As already noted, normal speech production can be modeled as the unidirectional and sequential top-down activation of nodes from semantics to phonology. But the production of poetic speech is bidirectional (from semantics to phonology and back again), nonsequential (activation can start at any node), and characterized by excessive-and in some cases, uncontrollable-priming: words lead to words, syllables to similar syllables, rhymes to rhymes, and sometimes, names to anagrams.

\section{Conclusion}

Saussure abandoned his research in part because he could not answer two questions. First, did the anagrams in fact exist? And second, if they did exist, what was their origin and function? The present study is intended to answer the latter question, but of course fundamental doubts about the former question could make this answer moot.

Unfortunately, I do not think there can be a definitive resolution to the question of the anagram's reality. The human capacity for pattern recognition may easily go into overdrive, as witnessed, for example, by a notorious attempt to read a prophecy about the John F. Kennedy assassination out of the Hebrew text of the Bible (Witztum et al. 1994; Drosnin 1997). Some of the anagrams "found" by Saussure and by those who followed his lead - the anagram hunters of the 1960s and 1970s - may in fact be pure fantasy. A standard procedure for disproving an overzealous pattern recognition scheme consists in finding similar patterns in a blatantly absurd and random context, thus showing that, if the rules are flexible enough, such patterns can be found everywhere (e.g., Bar-Hillel et al. 1998). This can easily be done with Saussurian anagrams - in fact right now, just as I was typing this word, I noticed that it more or less contains my name: M. Gronas. However, the ease of finding a pattern does not in itself disprove the existence of the pattern.

As mentioned before, Saussure played with the idea of proving non- 
randomness of the anagrammatic patterns statistically but conceded that such a task would be beyond his mathematical expertise (Nava 1968: 81). In the seventies - the heyday of anagrammatic research-skeptics called for verification by the methods of computational linguistics, then in its infancy (Karlgren 1973). To my knowledge, this call still remains unheeded and for good reason. The phenomenon of the anagram, as defined by Saussure, is quite vague and hardly allows for formalization. The "theme word" can be pretty much any proper name (and in his later notebooks, any noun) relevant to the text; the minimal components of the anagram can be either phonemes, or diphones, or syllables; the sequence of components can be the same or different from that in the target word; the components themselves can be either adjacent or, more frequently, separated by an unspecified number of filler syllables. All of this involves so much variability that a statistical definition of the anagram will hardly be useful. ${ }^{25}$

However, some anagrams are just obvious - not to a single scholar but to a community of culturally competent readers. For example, while reading Mandel'shtam's "Ode to Stalin," no educated Russian will fail to hear the name Stalin in the two rhyming lines that end in "stali" and "zastali." Starobinski (2005: 563-67) cites a wonderful example of another obvious anagram in the fifth sonnet of Petrarch's (1976: 40) Canzoniere (Rime sparse):

25. Even if one comes up with a definition, any resulting statistical analysis will be inconclusive. Let us assume, for example, that the anagram is a sequence of phonetic elements within the line of a poetic text (e.g., a + po +lo in the Saturnian poem discussed above), roughly corresponding to the phonetic elements in a proper name relevant to that line (e.g., "Apollo"). The probability that this sequence will occur in a random line of text can be estimated from a corpus (say, of all Latin texts). Depending on how frequent these elements and their combinations are in a given language, this probability may be relatively low or high. If a certain sequence turns out to be extremely rare, it would indeed constitute an argument in favor of intentionality (or some kind of nonconscious motivation)-but the anagram in such a case is likely to be one that is obvious to begin with. In most cases, probability alone (i.e., the likelihood that any particular set of syllables will occur in a random line) will not be enough for us to make a judgment on intentionality/motivation with sufficient confidence. And if a sequence has a high probability of occurrence, it may still be intentional (or nonrandom) because, for example, the target name consists of a small number of frequently occurring syllables. To produce a better estimate, one would need to compare the probability of occurrence of the target syllables in the language as a whole to the probability of their occurrence in texts associated with the relevant proper name. This latter probability, however, is impossible to determine, since the sample size always consists of just one instance. If Saussure's claim was that most poems devoted to Apollo tend to contain anagrams, then one could compare the conditional probability estimated on the corpus of Apollo-related texts against the corpus of all texts. But since his claims are limited to unique handpicked cases, they cannot be either proved or disproved statistically. I would like to thank computational linguists Anna Rumshisky (2008) (Brandeis) and Sergey Bratus (2008) (Dartmouth), who confirmed my more or less intuitive statistical reasoning on this subject. 
Quando io movo i sospiri a chiamar voi, e 'l nome che nel cor mi scrisse Amore, LAUdando s'incomincia udir di fore il suon de' primi dolci accenti suoi;

Vostro stato REal, che 'ncontro poi, raddoppia a l'alta impresa il mio valore; ma TAci, grida il fin, ché farle onore è d'altri omeri soma che da' tuoi.

(When I move my sighs to call you and the name that Love wrote on my heart, the sound of its first sweet accents is heard without its LAU-ds.

Your RE-gal state, which I meet next, redoubles my strength for the high enterprise; but "TA-lk no more!" cries the ending, "for to do her honor is a burden for other shoulders than yours.”) (Prose translation by Robert Durling)

In this sonnet, the presence of the anagram is beyond a doubt not because it is immediately available to the reader but because Petrarch himself highlighted the syllables of the name Laureta (the diminutive of Laura) by putting them in capital letters. The sonnet itself is a glorification of Laura's name, which "Love wrote on [the poet's] heart," and this motivates the insertion of the syllables into its phonetic texture (for a detailed analysis, see Starobinski 2005: 564-66). Still, one is left to wonder whether Petrarch had the device in mind beforehand, or only realized the presence of the pattern while composing and decided to keep going with it, or perhaps even - much to his own surprise - found the syllables of the beloved name in the already written poem. In any event, if Petrarch had not marked the syllables himself, a scholar who discovered this anagram would have had no proof of it beyond the pattern itself.

If at least some anagrams are "real" (i.e., not random and either consciously or unconsciously motivated), then other observed anagrams may be real as well. Or again, they may not be. The question becomes how convincing - from the philological, historical, and psychological points of view - each particular instance is. What I hope to have demonstrated in this study is the theoretical possibility and indeed plausibility of the anagram's existence. The mnemopoetic approach holds that poetic creativity is based on a process of mnemonic elaboration that utilizes various types of priming as phonetic and semantic constraints. If the anagram is a result of priming exerted by a significant word that is kept at the back of the poet's memory at the time of composition, then the presence of anagrams in some poems should not be surprising.

This view also helps clarify the question of intentionality-a question strangely neglected by Saussure, who for the most part seemed to believe 
in the conscious use of the anagram, but raised in later anagrammatic scholarship. The consensus seems to be that the anagram is more likely to be an unconscious phenomenon rather than an intentional device"subliminal" in the words of Jakobson (1980), "between intellect and intuition" according to T. Craig Christy (1999: 557): ${ }^{26}$ hence the absence of the kind of historical evidence that Saussure was looking for. At the same time, as in the case of Petrarch's sonnet, some notable intentional uses of the anagram have also been observed. If the anagram is the result of semantic and perceptual priming, this continuum-from the nonconscious (more frequent) to the intentional (less so) - is to be expected. Since priming is a form of implicit, nonconscious memory, priming effects do not have to reach the threshold of consciousness and may remain unnoticed. However, nothing prevents a poet from recognizing such effects by way of introspection and even using them intentionally as a poetic device.

Finally, the proposed view of the anagram (and of poetic creativity in general) may have some empirical implications and offer testable predictions. In particular, if priming plays such an important role in the mechanism of poetic creativity, poets should exhibit above average priming effects in the usual kinds of experiments on priming, such as the repetition priming paradigm (i.e., when prior exposure to a stimulus facilitates the processing of a semantically or perceptually related stimulus). Of course, an inherent difficulty in designing such experiments would be how to define poet and poetry. The present discussion only concerns what I call "para-oral" poetry, dependent on social practices of memorization and recitation. This would include such modern traditions as North American rap or Lebanese Zajal poetry but probably exclude some varieties of contemporary Western free verse.

The importance of priming in poetry may also explain the oft-repeated but informal observation that - a few famous exceptions notwithstanding-poetic creativity tends to peak (at least in terms of quantity) at a relatively young age and goes downhill from there. This may have to do with the well-studied age-related decline in priming transmission (e.g., Cohen and Faulkner 1986; Juncos-Rabadan 2006) - the same reason why as we age we find-or rather lose-more and more words on the tips of our tongues.

26. In his perspicacious study of the problem of the anagram's intentionality, Christy (1999: 559) mentions in passing the possibility of the mnemonic use of the anagram without exploring the wider cultural and cognitive implications of this conjecture. 


\section{Postscript I: In Which Tentative Historical Evidence for the Anagram May Be Found but Not Where Saussure Was Looking for It}

What about the third problem that plagued Saussure: if the anagram was widely used, then why was it never mentioned or described? Part of the answer to this question has already been presented: the anagram is more likely to be a nonconscious phenomenon. Even when used intentionally, it was an occasional experiment rather than a systematic poetic device worthy of inclusion in poetry manuals. And that is where Saussure was looking for evidence: "I have no further explanation of the fact, so difficult to understand or believe, that not a single Latin author writing a De re metrica or discussing poetic composition in a general way should appear to know, or even to wish to know, that the fundamental basis of poetic composition is to take as a framework the logograms [i.e., anagrams] of a name or of a phrase" (quoted in Starobinski 1979: 103). Saussure greatly exaggerated the importance of the anagram as a specifically poetic device. But if the mnemopoetic understanding of the anagram is correct, then we would expect a wider and more explicit use of anagrams or similar patterns in the domain of practical mnemonics, which was considered a branch of rhetoric rather than poetics proper. And this may in fact be the case.

Little has survived of the once thriving ars memorativa practiced in classical antiquity. ${ }^{27}$ The oldest source we have on it is a short section of a Sophist fragment called the Dialexeis or Dissoi Logoi (Double Speeches) dating from the fourth century BCE; the second oldest source is a chapter on mnemonics from the rhetorical treatise Ad Herennium dating from the first century BCE and formerly attributed to Cicero. And it so happens that both these texts do include explicit descriptions of a mnemonic device rather similar to the Saussurian anagram. In the Dialexeis we read:

What you hear, place on what you know. For example, (the name) Chrysippus is to be remembered; we place it on chrysos (gold) and hippos (horse). Another example: we place [the name] [P] yrilampes on pyr (fire) and lampein (shine).

So much for [proper] names. (Quoted in Yates 1966: 30) ${ }^{28}$

In order to memorize the proper name, we are advised to decompose it into its constituent parts. The mnemonic operations "chrysos (gold) + hip-

27. For the by now classic account of the history of ars memorativa in antiquity and the Middle Ages, see Yates 1966.

28. Yates seems to indicate that pyrilampes is simply the word for glowworm, but it is also a proper name, mentioned, e.g., in Plato's Gorgias $481 \mathrm{D}$ and ${ }_{513} \mathrm{~B}$ and in his Charmides 158A. The word is treated as a proper name in the authoritative Diels (1996 [1952], 2:416) edition of Dissoi Logoi. For an analysis of this and other Greek and Latin mnemonic devices from the cognitive perspective, see Small 1997. 
pos $($ horse $)=$ [proper name $]$ Chrysippus" and "pyr (fire) + lampein (shine) $=$ [proper name $]$ Pyrilampes" are similar, for example, to the anagram of the name of the god Agni Agniras that Saussure found in the Vedic hymn to this god: "anga (conjunction) + girah (songs) = Agni Agniras" (see Starobinski 1979: 23).

In the Ad Herennium, we find a recommendation on how to memorize a line of poetry:

Iam domum itionem reges Atridae parant

(And now their homecoming the kings, the sons of Atreus, are making ready)

If we wish to remember this verse, in our first background we should put Domitius, raising hands to heaven while he is lashed by Marcii Reges - that will represent "Iam domum itionem reges." (Cicero 1954: 34)

Here the first part of the poetic line ("domum itionem reges") is mnemonically hooked on proper names (Domitius and the Reges, the names of two prominent Roman families) that contain the same syllables in the correct order. The action described is intended to evoke a striking and memorable image (a nobleman being lashed by other noblemen) that will cement in the mind the names of the participants and, through the names (Domitius, Reges), the similar-sounding line (domum itionem reges). This mnemonic operation is similar to the Saussurian anagram of Apollo hidden in the line "Donom amplom victor ad mea templa portato" in the ancient Roman oracle. Using the terminology of ars memorativa, one could say that the line is mentally "placed" on the name Apollo in the same way that the poetic line in Ad Herennium is "placed" on the names of Domitius and the Reges.

The third oldest surviving manual on the art of memory, included in Quintilian's Institutio Oratoria (The Orator's Education; 2002, 5:74), also contains a description of an anagram-like mnemonics based on proper names, and so do many medieval treatises on mnemotechnics. ${ }^{29}$ Moreover, the anagram-like patterns (the method known as keyword mnemonics) is still

29. See Carruthers and Ziolkowski (2002: 9-11) on "rebus-like associations to remember names" which survived throughout the history of medieval rhetoric as part of memoria verborum, "memory for words." Thus the fifteenth-century Catalan scholar Francesc Eiximenis (2002: 203), in his treatise "On Two Kinds of Order That Aid Understanding and Memory," advises:

If I wish to memorize the names of some men, I will put them together in some syllables from which I will make a new word. Say that I wish to remember a man called "Aurelius," another called "Ximus," another called "Linus," another called "Arnaldus," and another named "Torquatus." From the first syllable of these names I will create the word "Auxiliator," so that the first syllable, which is "Au," represents to me "Aurelius," and the second, which is "Xi," "Ximus," and the third, which is "Li," represents to me "Linus," and the fourth, which is "A," represents "Arnaldus," and fifth, which is "Tor," stands for "Torquatus." 
used by modern practitioners of the art of memory. For example, the mnemonist S. (Solomon Shershevsky), the hero of Aleksandr R. Luria's seminal study The Mind of a Mnemonist, describes using anagram-like bundles of phonological and semantic clues for memorizing lists of names and lengthy texts. ${ }^{30}$ Thus both ancient sources and contemporary data give credence to the view that the anagram, or anagram-like patterns, may be used mnemonically.

It is worth mentioning that ancient name-based mnemonics as well as the two main subjects of this article-the anagram and the tip-of-thetongue state - all deal predominantly with proper names. Most of the anagrams that Saussure described were proper names. Statistical research on the tip-of-the-tongue phenomenon has shown that the majority of such states $(65-85$ percent) has to do with proper names (see Schwartz 2002: 30). Finally, as we have seen, the oldest examples of anagrammatic mnemonics in Dialexeis and in Ad Herennium are also based, in large part, on proper names.

All this is understandable in that proper names have a special cognitive status: they are arbitrary and unique, they refer to just one object rather than to a type or category of object, and hence their semantic networks are underdeveloped (Cohen 1990; Burke et al. 2004: 164). This is why proper names are notoriously difficult to recall. ${ }^{31}$ On the other hand, the fact that a name refers to just one distinct individual allows familiar or important names ${ }^{32}$ (one's own name, the name of the beloved, or the name of a god)

30. Asked by the experimenter to memorize parts of The Divine Comedy in the original, Shershevsky (who did not know Italian) came up with an anagram-like technique. Here is Shershevsky's account of the sequence of words and images he used to memorize the first line: "Nel mezzo del cammin di nostra vita" (In the middle of our life's journey):

$(\mathrm{Nel})-\mathrm{I}$ was paying my membership dues when there, in the corridor, I caught sight of the ballerina $\mathrm{Nel}$ 'skaya.

(mezzo) - I myself am a violinist; what I do is to set up an image of a man, together with [Russian: vmeste] Nel'skaya, who is playing the violin.

$(d e l)$ - There is a pack of Deli Cigarettes near them.

(cammin)-I set up an image of a fireplace [Russian: kamin] close by.

(di) - Then I see a hand pointing towards the door [Russian: dver'].

(nostra) - I see a nose [Russian: nos]; a man has tripped, and in falling, gotten his nose pinched in the door way $(t r a)$.

(vita - He lifts his leg over the threshold, for a child is lying there, that is, a sign of lifevitalism. (Luria 1968 [1965]: 45-46)

31. See Valentine et al. 1996: $85^{-116}$ for an overview of theories dealing with the retrieval of proper names.

32. Psychologists have found that letters occurring in one's own name are perceived by informants as more attractive. This phenomenon is known as the "name letter effect." See Nuttin 1985 for the first experimental demonstration and Valentine et al. 1996: 8-15 for an analysis of suggested explanations. One might expect a similar effect with other important 
to develop intense and emotionally laden networks of semantic connections. This turns these names into powerful primes, and as a result, they become very difficult to forget and hence perfect mnemonic "places" for supporting memorization. Thus personal names are both easy to forget but also handy as mnemonic aids; and this is why, in the oldest mnemonic manuals, we find both strategies to remember names by decomposing them into phonetic and semantic elements (Chrysippus = chrysos "gold" and hippos "horse") and strategies to remember texts by decomposing them into familiar names (domum itionem reges $=$ Domitius + Reges). These mnemonic traditions themselves could be one of the sources of the anagrammatism in Greek and Latin poetry. Ars memorativa was part of practical rhetoric and thus played an important role in the educational curriculum. A schoolboy assigned to play with mnemonic decompositions-such as the one about poor Domitius lashed by the obnoxious Reges - in order to learn poetry by heart might well develop a liking for such games and use it in his own poetry later on.

\section{Postscript II: In Which Mandel'shtam and Saussure (Maybe) Meet}

As mentioned earlier, Saussure found anagrams even in modern poetry and finally, in 1909, decided to ask Pascoli whether he used anagrams consciously (Nava 1968). Pascoli never replied to Saussure's detailed second letter, and the scholar finally abandoned his research.

However, there was another contemporary who, roughly ten years later, would write something like the anagrammatic poet's confession that Saussure was expecting - in vain - from Pascoli. This other poet was Mandel'shtam.

Mandel'shtam had traveled to Switzerland twice (1909, 1910), and during his first and longer stay (July to September 1909) he may well have met with Saussure. The young Mandel'shtam's philological specialty was Romance languages and literatures. In 1908, before his Swiss trip, he took classes in Old French literature at the Sorbonne and later, in 1909, enrolled in courses on Romance philology at Heidelberg (Dutli 2005: 48-51; Nerler 1994). These were precisely the subjects that Saussure was teaching in Geneva: hence it seems plausible that Mandel'shtam could have dropped in at one of Saussure's lectures. ${ }^{33}$

proper names (such as the name of the beloved), although, to my knowledge, such experiments have not yet been conducted.

33. In addition, Mandel'shtam and Saussure even happened to have a mutual acquaintance, the leading Russian symbolist poet and philosopher Viacheslav Ivanov (1866-1949). Ivanov was the young Mandel'shtam's mentor, the reader of his first poetic attempts, and the 
If Saussure, who died in 1913, could have read just five lines from Mandel'shtam's 1923 poem "Nashedshii podkovu" ("The Horseshoe Finder"), he would have found them most intriguing. The very first line of this passage seems like a perfect explication of an anagram: "Trizhdy blazhen, kto vvedet v pesn' imia" (Thrice blessed he who sets name into song). This is a direct description of the anagrammatic principle: a proper name is set into (literally "inserted into" or "led into") a poem. But Mandel'shtam (1990, 1:146) goes on to explain why one might use an anagram, and his reasons seem to be mnemonic:

\section{Украшенная названием песнь Дольше живет среди других- \\ Она отмечена среди подруг повязкой на лбу, Исцеляющей от беспамятства}

(The song adorned by a name Lives longer amid the others-

She is marked out amid her companions by the band on her brow Which saves her from oblivion.) (Modified translation by Jane Miller.)

Thus if this reading of the passage is correct, the name is inserted into the fabric of a poem in the form of dispersed phonetic and semantic clues to it, and this anagrammatic pattern becomes the headband, "the band on her brow," a mnemonic sign that provides for the poem's cultural survival ("saves her [i.e., the song, the poem] from oblivion"). ${ }^{34}$

most frequent addressee of his surviving letters from 1908 and 1909. While living in Geneva in the early 19oos, Ivanov had studied Sanskrit under Saussure, and he maintained the contact afterward (quoted in Meylakh 1976: 108). On the eve of his Swiss trip, Mandel'shtam $(1997,4: 13)$ sent Ivanov a letter asking whether the latter was planning to be in Switzerland so that the two poets could meet there. Ivanov's answer does not survive, but it is plausible that in reply he could have told Mandel'shtam that, although he himself would not be there, Mandel'shtam - since he was interested in Romance philology-should find an interesting interlocutor in Saussure. According to Mikhail Meylakh's ingenious hypothesis, conversations with Saussure could have influenced Ivanov's own theory of the "internal phonic image," a concept that is in many respects reminiscent of the Saussurean anagram (ibid.: 13-14). If Meylakh's guess is correct, Mandel'shtam could have learned about anagrams from Ivanov himself.

34. This is of course a risky and admittedly somewhat playful reading of the passage. The obscurity of late Mandel'shtam is usually the result of a condensed and elliptical poetic diction - what has been termed a "poetics of omitted links" (Gasparov 2001: 193-26o; see also Levin 1969; Ronen 1973; Semenko 1997: 143), which puts the reader (and the scholar) into the position of a decoder or puzzle solver. The "omitted links" could be either internal, i.e., logical and associative connections within the text itself, or external, such as implicit allusions and hidden quotations. "The Horseshoe Finder" (which is subtitled "A Pindaric Fragment") abounds in hidden allusions to Pindar's odes that may clarify the poem's imagery. 
Did Mandel'shtam-one of the most prolific anagram writers of the twentieth century, a poet who used anagrams surprisingly consciously (see the Stalin line in his ode) - in fact attend one of Saussure's lectures when the scholar happened to be discussing anagrams? Could Mandel'shtam have then developed his own theory of the anagram, one similar to that presented here? Have I read too much into Mandel'shtam's lines, just as Saussure read anagrams into the poems of the unsuspecting Pascoli? We will never know.

\section{References}

Auden, W. H., and John Garrett, eds.

1935 The Poet's Tongue: An Anthology (London: G. Bell).

Bachellier, Jean-Louis

1973 "Rimebaldiane miousic: Les maîtres-mots-chanteurs de Rimbaud," SubStance 3 (7): $127-37$.

Bar-Hillel, Maya, Dror Bar-Natan, and Brendan McKay

1998 "The Torah Codes: Puzzle and Solution," Chance 11 (2): 13-19.

Thus as has been noted by Mandel'shtam scholars (Broyde 1975: 185; Dobritsyn 1994: 117), the image of the band (or fillet- "poviazka na lbu") that "marks" the song (or poem) and "saves it from oblivion" is a reference to Pindar's frequent description of Mnemosyne and the Muses wearing a fillet (or frontlet, or diadem): $\chi \rho v \sigma \alpha \dot{\mu} \pi \nu \xi$ (literally, golden-banded). In light of this allusion, Steven Joseph Broyde (1975: 184) interprets "the name that marks the song" as the poem's title: "The title clearly stands in relation to a poem (on a printed page) as the fillet does to the one who wears it - on the top." According to Broyde, having a title makes a poem more distinct and thus ensures its survival in its readers' memory. In my opinion, this interpretation is problematic: even if one agrees with the idea that a poem with a title is, in some sense, more memorable, the literal meaning of the first line of the passage ("Thrice blessed he who sets [inserts] name into song") seems to contradict such a reading. "Setting or inserting into" implies placing the name inside the text rather than "putting it on top" as a title. In addition, the Russian word imia (name), used in the first line, never means "title" and always refers to a personal name.

A more convincing interpretation has been suggested by Clare Cavanagh (1995) in a close reading of the poem included in her book Osip Mandelstam and the Modernist Creation of Tradition. Cavanagh (ibid.: 176) notes that Pindar "uses the image of fillet or headband to symbolize the poem's dedication to the lofty patron whose name would 'shine from afar' at the head of the ode that would concentrate his deeds for the posterity." Indeed, Pindar's victory odes are dedicated to the winners of athletic contests, and the names of their patrons both serve as de facto titles and are often repeated in the texts themselves. Therefore, according to Cavanagh, "the name that marks the song" is that of a patron, a reflection of Mandel'shtam's nostalgia for the idealized golden age of harmony between power and poetry, when each helped the other in the struggle against oblivion. My anagrammatic reading of this passage does not contradict but rather complements Cavanagh's interpretation: the name of the poem's addressee (a patron, the subject of a hymn or epitaph) is a frequent subject of Saussurian anagrams. And as has been discussed above, in Mandel'shtam's only attempt at a dithyrambic ode dedicated to a would-be patron, his "Ode to Stalin," the name of the addressee is indeed literally inserted into the poem by virtue of being a surreptitious rhyme to two lines (Stalin / stali / zastali). 
Baudrillard, Jean

1993 Symbolic Exchange and Death, translated by Iain Hamilton Grant (London and Thousand Oaks, CA: Sage).

Beekes, Robert

1998 "Hades and Elysion," in Mir Curad: Studies in Honor of Calvert Watkins, edited by Jay Jasanoff, H. Craig Melchert, and Lisi Olivier, 17-28 (Innsbruck, Austria: Institut für Sprachwissenschaft der Universität Innsbruck).

Benchich, Zhiva

1997 "Kategoriia pamiati v tvorchestve Osipa Mandel'shtama," Russian Literature 42: $115-36$.

Bevis, Matthew

2007 "Joyce's Love Letters," Fames Foyce Quarterly 44 (2): 354-57.

Blum, Herwig

1969 Die antike Mnemotechnik, Spudasmata 15 (Hildesheim, NY: Olms).

Bratus, Sergey

2008 Conversation with author, March 8.

Brinkley, Tony, and Raina Kostova

2003 "The Road to Stalin: Mandelstam's 'Ode to Stalin' and 'The Lines on the Unknown

Soldier,"” Shofar: An Interdisciplinary fournal of Jewish Studies 21: 2-62.

Brodsky, Joseph

1990 "Let Them Read Proust (Interview with Joseph Brodsky)," Economist (U.S.), October

$13,97-98$

Brown, A. S.

1991 "A Review of the Tip-of-the-Tongue Experience," Psychological Bulletin 109 (2): 204-23.

Broyde, Steven Joseph

1975 Osip Mandel'štam and His Age (Cambridge, MA: Harvard University Press).

Burke, Deborah M., Jill Kester Locantore, Ayda A. Austin, and Bryan Chae

2004 "Cherry Pit Primes Brad Pitt: Homophone Priming Effects on Young and Older Adults' Production of Proper Names," Psychological Science 15 (3): 164-70.

Callus, Ivan

2002a "Jalonnante and Parathlipse: Encountering New Terminology in Ferdinand de

Saussure's Researches into Anagrams," Cahiers Ferdinand de Saussure: Revue Suisse de Linguistique Générale 55: 169-202.

2002b "A Chronological and Annotated Bibliography of Works Referring to Ferdinand de Saussure's Anagram Notebooks," Cahiers Ferdinand de Saussure: Revue Suisse de Linguistique Générale 55: 269-95.

Camilleri, Rosemary

1983 "Plumtree's Meatpot: A Cryptogram in Ulysses," Fames Foyce Quarterly 20 (4): 461-62.

Carruthers, Mary J., and Jan M. Ziolkowski, eds.

2002 The Medieval Craft of Memory: An Anthology of Texts and Pictures (Philadelphia: University of Pennsylvania Press).

Cavanagh, Clare

1995 Osip Mandelstam and the Modernist Creation of Tradition (Princeton, NJ: Princeton University Press).

Chekhov, Anton Pavlovich

1915 [1885] "A Horsey Name," in Russian Silhouettes: More Stories of Russian Life, translated by Marian Fell, 272-78 (New York: Scribner).

Christy, T. Craig

1999 "Between Intellect and Intuition: Saussure's 'Anagrams' and the Calculus of the Auri-(Ora)cular," in Interdigitations: Essays for Irmengard Rauch, edited by Gerald F. Carr, Wayne Harbert, and Lihua Zhang, 557-68 (New York: Peter Lang). 
Cicero, Marcus Tullius

1954 Ad C. Herennium de ratione dicendi (Rhetorica Ad Herennium), edited and translated by Harry Caplan (Cambridge, MA: Harvard University Press).

Cipra, Barry 2003 "Algorithmics = Has Trim Logic," Science 299: 650-51.

Cohen, Gillian 1990 "Why Is It Difficult to Put Names to Faces," British Fournal of Psychology 81: 287-97.

Cohen, Gillian, and Dorothy Faulkner 1986 "Memory for Proper Names: Age Differences in Retrieval," British Fournal of Developmental Psychology 4: 187-97.

Cole, Thomas 1969 "The Saturnian Verse," Yale Classical Studies 21: 3-73.

Deguy, Michel 1969 "La folie de Saussure," Critique 260: 20-26.

De Looze, Laurence 1988 "'Mon nom trouveras': A New Look at the Anagrams of Guillaume de Machaut; The Enigmas, Responses, and Solutions," Romanic Review 79: 537-57.

Diels, Hermann 1996 [1952] Die Fragmente der Vorsokratikier, Griechisch und Deutsch von Hermann Diels, herausgegeben von Walther Kranz, 3 vols. (Zurich: Weidmann).

Dobritsyn, A. A.

1994 “'Nashedshii podkovu': Antichnost' v poezii Mandel'shtama," Philologica 1 (1-2): $115^{-31 .}$

Drosnin, Michael

1997 The Bible Code (New York: Simon and Schuster).

Dutli, Ralph 2005 Vek moi, zver' moi: Osip Mandel'shtam; Biografia, translated by Konstantin Azadovskii (Saint Petersburg: Akademicheskii Proekt).

Eiximenis, Francesc

2002 "On Two Kinds of Order That Aid Understanding and Memory," translated by Kimberly Rivers, in Carruthers and Ziolkowski 2002: 192-204.

Elizarenkova, Tatyana J.

1995 Language and Style of the Vedic Rsşis (Albany: State University of New York Press).

Florensky, Pavel

1997 [1914] The Pillar and Ground of the Truth, translated by Boris Jakim (Princeton, NJ: Princeton University Press).

Foley, John Miles 1988 The Theory of Oral Composition: History and Methodology (Bloomington: University of Indiana Press).

Freidin, Gregory

1982 "Mandel'shtam's ‘Ode to Stalin': History and Myth,” Russian Review 41 (4): 400-26. 1987 A Coat of Many Colors: Osip Mandelstam and His Mythologies of Self-Presentation (Berkeley: University of California Press).

Gagliardo, Francesca 1996 "Indagine computerizzata di anagrammi nel primo sonetto di W. Shakespeare," Confronto Letterario: Quaderni del Dipartimento di Lingue e Letterature Straniere Moderne dell'Università di Pavia e del Dipartimento di Linguistica e Letterature Comparate dell'Università di Bergamo 13 (25): 179-89.

Gandon, Francis 2002 De dangereux édifices: Saussure lecteur de Lucrèce; Les cahiers d'anagrammes consacrés au "De rerum natura" (Louvain, Belgium: Peeters).

Gasparov, Mikhail 2001 O russkoi poezii (Saint Petersburg: Azbuka). 
Ginzburg, Lidiia 1974 O lirike (Leningrad: Sov. Pisatel').

Goethe, Johann 1964 Selected Verse, introduced and edited by David Luke (Harmondsworth, UK: Penguin).

Gorni, Guglielmo 1990 Lettera nome numero. L'ordine delle cose in Dante (Bologna, Italy: Il Mulino).

Guy, Laurence 1996 "Les anagrammes cosmopolites de l'auteur dans son oeuvre, ou l'identité renversée de Vladimir Nabokov," Cahiers du Monde Russe 37 (3): 337-48.

Hajdú, Helga 1967 Das Mnemotechnische Schrifttum des Mittelalters (Amsterdam: Bonset).

Hardy, Ineke, and Elizabeth Brodovitch 2003 "Tracking the Anagram: Preparing a Phonetic Blueprint of Troubadour Poetry," in

The Court Reconvenes: Courtly Literature across the Disciplines, edited by Barbara K. Altmann and Carleton W. Carroll, 199-213 (Cambridge: D. S. Brewer).

Havelock, Eric Alfred 1963 Preface to Plato (Cambridge, MA: Belknap Press, Harvard University Press). 1971 Prologue to Greek Literacy: Lectures in Memory of Louise Taft Semple (Cincinnati, OH: University of Cincinnati).

1976 Origins of Western Literacy (Toronto: Ontario Institute for Studies in Education). 1982 The Literate Revolution in Greece and Its Cultural Consequences, Princeton Series of Collected Essays (Princeton, NJ: Princeton University Press).

1986 The Muse Learns to Write: Reflections on Orality and Literacy from Antiquity to the Present

(New Haven, CT: Yale University Press).

Heaney, Seamus

2004 "The Rite Words in the Rote Order: Poetry in a Life." Public lecture delivered at Harvard University, Cambridge, MA, October 22.

Herrero Blanco, Angel

1996 "La 'sibilación escrita': Anagramatismo en la poesía de Antonio Machado," Bulletin Hispanique $9^{8}$ (1): 205-19.

Hesse, Petra 1989 Mythologie in moderner lyrik: Osip E. Mandel'štam vor dem Hintergrund des "Silbernen Zeitalters," European University Studies Series 16, Slavonic Languages and Literatures, vol. $3^{8}$ (Bern and New York: Peter Lang).

Higgins, Lynn 1982 "Literature 'à la lettre': Ricardou and the Poetics of Anagram," Romanic Review 73 (4): $473-88$.

Ivanov, Viacheslav 1972 "Dva primera anagrammaticheskikh postroenii v stikhakh pozdnego Mandel'shtama," Russian Literature 3: 81-87.

1999 "Old Novgorodian Nevide, Russian Nevidal': Greek Aidelos," UCLA Indo-European Studies 1: 283-93.

Ivanov, Viacheslav, and V. N. Toporov

1975 "Invariant i transformatsii v mifologicheskikh i fol'klornykh tekstakh," in Tipologicheskie issledovaniia po fol'kloru: Sbornik statei pamiati Vladimira Iakovlevicha Proppa (1895-197o), 44-74 (Moscow: Nauka).

Jakobson, Roman 1966 "Ushchekotal skacha," in Selected Writings, 4:603-10 (The Hague: Mouton). 1967 "Une microscopie du dernier Spleen dans les Fleurs du Mal," Tel Quel 29: 12-24. 1976 Hölderlin, Klee, Brecht: Zur Wortkunst dreier Gedichte, selected and introduced by Elmar Holenstein (Frankfurt am Main: Suhrkamp). 1980 "Subliminal Verbal Patterning in Poetry," Poetics Today 2: 127-36. 
Jakobson, Roman, and Lawrence G. Jones

1970 Shakespeare's Verbal Art in Th'expence of Spirit, De propietatibus litterarum, Series practica 35 (The Hague: Mouton).

James, Lori E., and Deborah M. Burke

2000 "Phonological Priming Effects on Word Retrieval and Tip-of-the-Tongue Experiences in Young and Older Adults," Fournal of Experimental Psychology: Learning, Memory, and Cognition 26 (6): 1378-91.

James, William 189o The Principles of Psychology, 2 vols. (New York: Holt).

Johnson, Anthony 1976 Sign and Structure in the Poetry of T. S. Eliot (Pisa, Italy: Editrice tecnico scientifica). Jones, Gregory V.

1989 "Back to Woodworth: Role of Interlopers in the Tip-of-the-Tongue Phenomenon," Memory and Cognition 17: 69-76.

Jones, Gregory V., and Sally Langford 1987 "Phonological Blocking in the Tip-of-the-Tongue State," Cognition 26: 115-22.

Juncos-Rabadan, Onésimo 2006 "The Phenomenon of the Tip of the Tongue in Aging," Psicothema 18 (3): 501-6.

Kahn, Andrew 1994 "Andrei Belyi, Dante and 'Golubye glaza i goriashchaia lobnaia kost”: Mandel'shtam's Later Poetics and the Image of the Raznochinets," Russian Review 53: 22-35.

Karlgren, Hans 1973 "Ferdinand de Saussure and His Anagrams," Statistical Methods in Linguistics 9: 91-100.

Katz, Boris 1999 “'My name or any such-like phantom': A Reading of Nabokov's 'Kakoe sdelal ia durnoe delo ...." Russian Review $5^{8}$ (4): 565-73.

Kopper, John 2007 Conversation with author, September 20.

Kovaleva, Irina 2005 "Psikheia u Persefony: Ob istokakh odnogo antichnogo motiva u Mandel'shtama," Novoe Literaturnoe Obozrenie 73: 203-16.

Kristeva, Julia 1969 "Pour une sémiologie des paragrammes," in Semeiotike: Recherches pour une sémanalyse, 113-46 (Paris: Seuil).

Lamont, Rosette C. 1974 "Joseph Brodsky: A Poet's Classroom," Massachusetts Review 15 (4): 553-78.

Lekmanov, Oleg A., ed. 1995 Mandel'shtam i Antichnost'(Moscow: Mandel'shtamovskoe obshchestvo). 1998 Kniga ob Akmeizme (Moscow: Izd. Moskovskogo kul'turologicheskogo litseia). 2003 Zhizn' Osipa Mandel'shtama (Saint Petersburg: Izd. zhurnala Zvezda).

Levin, Iurii 1969 "O nekotorykh chertakh plana soderzhaniia v poeticheskikh tekstakh. Materialy $\mathrm{k}$ izucheniiu poetiki O. Mandel'shtama," International Fournal of Slavic Linguistics and Poetics 12: $106-64$.

Levinton, Georgii A.

1977 “"Na kamennykh otrogakh Pierii . . .' Mandel'shtama: Materialy k analizu," Russian Literature $5(2): 123-70 ; 5(3): 201-36$.

Levinton, Georgii A., and Igor' P. Smirnov 1979 “'Na pole Kulikovom' Bloka i pamiatniki Kulikovskogo tsikla," Trudy otdela drevnerusskoi literatury 34: 72-95. 
Livy

2005 The Rise of Rome: Books One to Five, translated by T. J. Luce (Oxford: Oxford University Press).

Lord, Albert B.

1960 The Singer of Tales (Cambridge, MA: Harvard University Press).

Loseff, Lev

1986 "Who's the Hero of the Poem without One?" Essays in Poetics 11 (2): 91-104. 2007 Conversation with author, June 15.

Lotringer, Sylvere

1973 "The Game of the Name," Diacritics 3 (2): 2-9.

Luiselli, Bruno

${ }_{1967}$ Il verso saturnio (Rome: Edizioni dell'Ateneo).

Luria, Aleksandr R.

1968 [1965] The Mind of a Mnemonist: A Little Book about a Vast Memory (Malen'kaia knizhka o bol'shoi pamiati), translated by Lynn Solotaroff (New York: Basic Books).

Mandel'shtam, Nadezhda

1970 Vospominaniia (New York: Izd-vo im. Chekhova).

1974 Hope Abandoned, translated by Max Hayward (New York: Atheneum).

Mandel'shtam, Osip

1979 The Complete Critical Prose and Letters, edited by Jane Gary Harris, translated by Jane

Gary Harris and Constance Link (Ann Arbor, MI: Ardis).

1990 Sochineniia: V dvukh tomakh, edited by P. M. Nerler, A. D. Mikhailov, and Sergei Sergeevich Averintsev (Moscow: Khudozh. lit-ra).

1997 Sobranie sochinenii v chetyrekh tomakh, edited by P. Nerler, A. Nikitaev, Iu. Freidin, and

S. Vasilenko (Moscow: Art-Biznes-Tsentr).

Matasovic, Ranko

1996 A Theory of Textual Reconstruction in Indo-European Linguistics (Frankfurt am Main and

New York: Peter Lang).

Mathieu, Jean-Claude

${ }_{1984}$ La poésie de René Char, ou, le sel de la splendeur (Paris: J. Corti).

McNamara, Timothy P.

2005 Semantic Priming: Perspectives from Memory and Word Recognition (New York: Psychology).

Meyer, Antje S., and Kathryn Bock

1992 "The Tip-of-the-Tongue Phenomenon: Blocking or Partial Activation?" Memory and Cognition 20 (6): 715-26.

Meyer, David E., and Roger W. Schvaneveldt

1971 "Facilitation in Recognizing Pairs of Words: Evidence of a Dependence between

Retrieval Operations," Fournal of Experimental Psychology 90 (2): 227-34.

Meylakh, Mikhail

1975 "Ob imenakh Akhmatovoi. I: Anna," Russian Literature 10-11: 33-57.

1976 "A propos des anagrammes," L'homme 16 (4): 105-15A.

1978 "Troubadours et anagrammes (structures anagrammatiques dans la chanson X

d'Arnaut Daniel)," in Mélanges de philologie offerts à Charles Camproux, 1:149-58 (Montpel-

lier, France: Centre d'Études occitanes).

Miozzo, Michele, and Alfonso Caramazza

1997 "Retrieval of Lexical-Syntactic Features in Tip-of-the-Tongue States," fournal of

Experimental Psychology: Learning, Memory, and Cognition 23 (6): 1410-23.

Montant, Marie, and Johannes C. Ziegler 2001 "Can Orthographic Rimes Facilitate Naming?" Psychonomic Bulletin and Review 8 (2):

$35^{1-56 .}$

Nava, Giuseppe

1968 "Lettres de F. de Saussure a G. Pascoli," Cahiers Ferdinand de Saussure 24: 73-81. 
Neely, James H.

1991 "Semantic Priming Effects in Visual Word Recognition: A Selective Review of Current Findings and Theories," in Basic Processes in Reading, edited by Derek Besner and Glyn W. Humphreys, 264-336 (Hillsdale, NJ: Erlbaum).

Nerler, Pavel M. 1994 Osip Mandel'shtam v Geidel'berge (Moscow: Art-Biznes-Tsentr).

Nuttin, Jozef M.

1985 "Narcissism beyond Gestalt and Awareness: The Name Letter Effect," European fournal of Social Psychology 15 (3): 353-61.

Ong, Walter J. 1982 Orality and Literacy: The Technologizing of the Word (New York: Methuen).

Osherov, Sergei A., and I. A. Barsova 1995 “'Tristia' Mandel'shtama i antichnaia kul'tura," in Mandel'shtam i Antichnost', edited by O. A. Lekmanov, 188-203 (Moscow: Mandel'shtamovskoe obshchestvo).

Ossola, Carlo 1979 "Les 'ossements fossiles' de la lettre chez Mallarmée et chez Saussure," Critique: Revue générale des Publications Françaises et Étrangères 35: 1063-78.

Parry, Milman

1953 Serbo-Croatian Heroic Songs, vol. 1, collected by Milman Parry, edited and translated by Albert B. Lord (Cambridge, MA: Harvard University Press; Belgrade: Serbian Academy of Sciences).

Pavlov, Evgeny 1998 "Memory and the Scene of Writing in Mandelstam's Egipetskaia Marka: Unrolling the Manuscript," Slavic and East European Fournal 42 (4): 621-39.

Petrarch

1976 Petrarch's Lyric Poems: The "Rime Sparse" and Other Lyrics, translated and edited by Robert Plato Durling (Cambridge, MA: Harvard University Press).

1995 Phaedrus, translated with introduction and notes by Alexander Nehamas and Paul Woodruff (Indianapolis, IN: Hackett).

1998 Cratylus, edited and translated by C. D. C. Reeve (Indianapolis, IN: Hackett).

Przybylski, Ryszard 1966 “Arkadia Osipa Mandelsztama," Slavia orientalis 13 (3): 243-62.

1987 An Essay on the Poetry of Osip Mandelstam: God's Grateful Guest (Ann Arbor, MI: Ardis).

Quintilian

2002 The Orator's Education, vols. 1-5, edited and translated by Donald A. Russell (Cambridge, MA: Harvard University Press).

Rastier, François 1970 "A propos du saturnine," Latomus 29: 3-24.

Ricks, Christopher 2002 "Shakespeare and the Anagram," Proceedings of the British Academy 121: 111-46.

Risset, Jacqueline 1995 L'anagramme du désir: Sur la "Délie" de Maurice Scève (Paris: Fourbis, Distribution Distique).

Rodríguez Ferrándiz, Raúl 1998 Semiótica del anagrama. La hipótesis anagramática de Ferdinand de Saussure (Alicante, Spain: Publicaciones de la Universidad de Alicante).

Ronen, Omri

1973 "Leksicheskii povtor, podtext i smysl v poetike Mandel'shtama," in Slavic Poetics: Essays in Honor of Kiril Taranorsky, edited by Roman Jakobson, C. H. Schooneveld, and Dean S. Worth, 366-87 (The Hague: Mouton).

1977 "The Dry River and the Black Ice: Anamnesis and Amnesia in Mandel'štam's Poem 'Ja slovo pozabyl, čto ja xotel skazat',', Slavica Hierosolymitana 1: 177-84. 
Rosetti, Alexandru

1976 "On the Anagrams of Ferdinand de Saussure," Revue Roumaine de Linguistique 21 (4): $459-6$ o.

Rossi, Aldo

1968 "Gli anagrammi di Saussure: Poliziano, Bach, e Pascoli," Paragone: Rivista Mensile di Arte Figurativa e Letteratura 218: 112-27.

Rubin, David C.

1995 Memory in Oral Traditions: The Cognitive Psychology of Epic, Ballads, and Counting-Out Rhymes (New York: Oxford University Press).

Rumshisky, Anna

2008 Conversation with author, March 4.

Schlott, Wolfgang

1981 Zur funktion antiker göttermythen in der lyrik Osip Mandel'stams. European University

Studies Series 16, Slavonic Languages and Literatures, vol. 18 (Frankfurt am Main:

Peter Lang).

Schwartz, Bennett L.

2002 Tip-of-the-Tongue States: Phenomenology, Mechanism, and Lexical Retrieval (Mahwah, NJ:

Lawrence Erlbaum).

Semenko, Irina M.

1997 Poètika pozdnego Mandel'shtama: Ot chernovykh redaktsii k okonchatel'nomu tekstu (Moscow:

Mandel'shtamovskoe obshchestvo).

Shapiro, Gavriel

1991 "Anagrams in Lolita," Nabokovian 27: 34-37.

Shepheard, David

1983 "How Many Saussures? The Question of the Anagrams," Paragraph: A Fournal of Mod-

ern Critical Theory 2: 42-52.

Shoptaw, John 2000 "Lyric Cryptography," Poetics Today 21: 221-62.

Slowiaczek, Louisa M.

2000 "Phonological Representations in Prelexical Speech Processing: Evidence from

Form-based Priming," Fournal of Memory and Language 43 (3): 530-6o.

Small, Jocelyn Penny

1997 Wax Tablets of the Mind: Cognitive Studies of Memory and Literacy in Classical Antiquity

(New York: Routledge).

Starobinski, Jean

1979 Words upon Words: The Anagrams of Ferdinand De Saussure, translated by Olivia Emmet

(New Haven, CT: Yale University Press).

2005 "Lettres et syllabes mobiles (Pétrarque, Ronsard, Saussure)," Lettere Italiane 57 (4): $55^{8-71 .}$

Taranovsky, Kiril

1976 Essays on Mandel'stam (Cambridge, MA: Harvard University Press).

Temple, Michael

1995 The Name of the Poet: Onomastics and Anonymity in the Works of Stéphane Mallarmé (Exeter,

Devon, UK: University of Exeter Press).

Terras, Victor

1966 "Classical Motives in the Poetry of Osip Mandel'štam," Slavic and East European fournal $10(3): 251-67$.

Tischler, Jennifer 2005 Conversation with author, September 10.

Toporov, Vladimir 1995 "O psikhofiziologicheskom komponente poezii Mandel'shtama," in Mif. Ritual. Simvol. Obraz. Issledovaniia v oblasti mifopoeticheskogo, 428-45 (Moscow: Progress). 
1999 "Ob anagrammakh v zagadkakh," in Issledovanïa v oblasti balto-slavianskoi dukhovnoi kul'tury. Zagadka kak tekst.2, edited by Vladimir Toporov, 69-8o (Moscow: Indrik).

Valentine, Tim, Tim Brennen, and Serge Brédart

1996 The Cognitive Psychology of Proper Names: On the Importance of Being Ernest (London: Routledge).

West, Martin L.

1973 "Indo-European Metre," Glotta 51: 161-87.

White, Keith, and James L. Beazel

1991 "The Manfred Anagram," Keats-Shelley Fournal: Keats, Shelley, Byron, Hunt, and Their Circles 40: 18-19.

Winnick, R. H.

2005 "Anagrammatic Patterns in Shakespeare's Sonnet 69," Notes and Queries 52 (2): 198-200.

Witztum, Doron, Eliyahu Rips, and Yoav Rosenberg 1994 "Equidistant Letter Sequences in the Book of Genesis," Statistical Science 9: 429-38. Wunderli, Peter

1972 Ferdinand de Saussure und die Anagramme: Linguistik und Literatur (Tübingen, Germany: Niemeyer).

Yates, Frances Amelia

1966 The Art of Memory (Chicago: University of Chicago Press). 